\title{
Mineralogy and Geochemistry of Fluvial-Lacustrine Pisolith Micronodules from the Roztoka Odrzańska, Odra River, NW Poland
}

\author{
Lukasz Maciąg 1,*iD, Urszula Rydzewska ${ }^{2}$, Artur Skowronek ${ }^{2}$ and Sylwester Salwa ${ }^{3}$ \\ 1 Institute of Marine and Environmental Sciences, University of Szczecin, Adama Mickiewicza 18, \\ 70-383 Szczecin, Poland \\ 2 Polish Geological Institute-National Research Institute, Pomeranian Branch, Wieniawskiego 20, \\ 71-130 Szczecin, Poland; urszula.rydzewska@pgi.gov.pl (U.R.); artur.skowronek@pgi.gov.pl (A.S.) \\ 3 Polish Geological Institute-National Research Institute, Holy Cross Mts. Branch, Zgoda 21, \\ 25-953 Kielce, Poland; sylwester.salwa@pgi.gov.pl \\ * Correspondence: lukasz.maciag@usz.edu.pl; Tel.: +48-91-444-23-71
}

Received: 17 November 2019; Accepted: 17 December 2019; Published: 20 December 2019

\begin{abstract}
Small-sized ferruginous micronodules or pisolith nodules, frequently occurring in inland freshwater systems in moderate climate zones, are important indicators of groundwater level changes and early diagenetic processes, especially within the Pleistocene post-glacial sedimentary systems, including swamps, peatbogs, rivers, or lakes. Compared to the other geochemical environments, pisolith nodules are usually dominated by iron hydroxides and oxides. In most cases, described micronodules indicate high phosphatization, significant contribution of allogenic detrital components, and low manganese content. The major aim of the article is to present textural, geochemical, and mineralogical variability of pisolith nodules recovered from the Roztoka Odrzańska, Odra river mouth area, NW Poland. We describe genetical relations between different types of pisoliths and try to interpret the possible formation phenomena. Analyzed loose ferruginous micronodules were separated from the lacustrine silty-clayey sapropel muds and gyttja, later analyzed using optical microscopy, SEM-energy dispersive x-ray (EDX), and XRD methods. As a reference material, we use archival iron bog ores and geochemical data of different types of nodules. Additionally, we describe previously unknown siderite-rich nodules found in neighboring sites of the Dabie Lake and the Szczecin Lagoon.
\end{abstract}

Keywords: micronodules; nodules; pisolith; ferruginous micronodules; lacustrine sediments; sapropel; gyttja; peat; Quaternary; iron bog

\section{Introduction}

Different kinds of nodules and micronodules are important components of rocks and sediments, being extensively found in all sedimentary environments, such as deep-sea basins [1] or terrestrial ferromanganese deposits [2,3]. Loose nodules and micronodules from the recent Quaternary lacustrine-fluvial environments are less frequent. Due to the weak economic potential and low contents of strategic metals, ferruginous pisoliths are not described very often in the literature [4-6]. Compared with the oceanic ferromanganese nodules, the lake, lacustrine, or river formed nodules and micronodules do not indicate increased contents of cobalt, nickel, copper, or rare earth elements. Considering the differences of trace element concentration and growth (nucleation) rate, the lacustrine nodules form much faster than oceanic polymetallic nodules, however in some cases do not significantly differ in shape, texture, or general chemical composition from the Fe-rich micronodules or nodules from oceanic basins [7]. 
The formation and occurrence of pisoliths in the young Quaternary sedimentary environments is a relatively puzzling and complex issue, being a subject of numerous mineralogical and geochemical studies [2,6,8-12].

The pisolith nodules and micronodules found in recent lacustrine-fluvial sediments, solid rocks, or soils are usually dominated by iron and called "iron bog ores" [13]. These kinds are usually associated with swamps, peats, and lacustrine sediments, being also classified as oxidized and reduced types [14,15]. The iron bog ores are also divided into fine ores (or "soft"), represented by loose deposits, and cemented ores (lump or "hard"), resembling slags and ferruginous sandstones or mudstones. Iron bog ores and associated Fe-rich or carbonate nodules are formed in the river valleys and lowlands, where the groundwater level is elevated [16].

Bog ores occur in three macro-morphological forms of decreasing size: (i) as a continuous, horizontal and cemented layer; (ii) as the randomly distributed ore blocks forming horizons, usually of $1 \mathrm{~cm}$ or more in diameter; (iii) loose ferruginous horizontal concentrations, mostly below $10 \mathrm{~mm}$ in diameter [13]. Additionally, the ferruginous material shows great micro-morphological variability, being found as pisoliths and continuous crusts (ferricretes or laterites), corresponding to ferric, plinthic, petroplinthic, and pisoplinthic horizons [17].

The pisoliths (also called pisoids or coniatolites) are formed as micronodules-spherical or ellipsoidal grains of concentric texture and a typical diameter of 2-10 $\mathrm{mm}$, classified in a group of ooclasts ( $>2 \mathrm{~mm}$ in diameter) or ooids $(<2 \mathrm{~mm})$. Pisoliths consist of a nucleus, one or more concentric layers and an outer casing (cortex). The growth of the cortex is continuous and occurs at the expense of dissolving and remobilizing the material from the nucleus, even to full replacement with new minerals. The outer layer is often characterized by greater hydration. The dominant processes are rehydration and, secondary, crystallization. In the terrestrial conditions, the mineral composition is dominated by hematite and goethite. Iron minerals often exhibit structural enrichment and incorporation into clays $[18,19]$.

The pisoliths form as a result of (i) chemical precipitation in turbulent water or the terrestrial environment; (ii) chemical and biochemical precipitation from calm water; (iii) early-diagenetic processes, especially in tropical and subtropical climates. The type (i) is evenly shaped, circular or ellipsoidal, and indicates flat external surfaces. Type (ii) often does not indicate a detritic nucleus and shows an irregular or concentric internal structure (type iii). Pisoliths usually do not indicate any organic structures [20], however, they may show bio- and geochemical origins and occur in rocks and sediments formed in various climate zones, from humid tropical climates to cool and dry polar climates [21]. Bio-processes may include biogenic dispersion of metals, biogeochemical precipitation in soils, especially within zones of plants activity, microbial processes, greater admixtures of siliceous material, such as diatoms, or influx of fertilizers rich in P and S. Geochemical processes are related mostly to climate zonation, variability, or redox conditions (dissolution and reprecipitation) and acquisition of $\mathrm{Fe}, \mathrm{Mn}, \mathrm{Al}$, and Si. Pisolith nodules may not display a detrital solid nucleus, such as quartz, and arise as a result of epigenetic processes, associated with the transformation of clay minerals [22].

Anand and Paine [23] classify iron and aluminum-rich pisoliths into four groups: (i) homogeneous, with no visible internal structure; (ii) lithorific, which shows a solid clavicle and a thin external mineral layer; (iii) pseudomorphic, in which all minerals are secondary, however, the original internal structure is still noticeable; (iv) concentric, consisting of a series of concentric layers. The individual types may indicate a number of fine admixtures of detrital or less soluble material.

According to the mineralogical classification of pisoliths, few types are distinguished: (i) carbonate (dominated by calcite, aragonite, siderite or rhodochrosite), (ii) bauxite, (iii) gibbsite, (iv) hematite, (v) goethite, (vi) chamosite, (vii) siliceous and (viii) phosphate. All types are found also in mixed compositions [24].

The mineral composition of pisolith micronodules is dominated by authigenic Fe-(Mn) oxides and oxyhydroxides (hematite, goethite, maghemite, ferrihydrite, feroxyhyte, wüstite, and rare native 
iron), as well as aluminum minerals (boehmite, gibbsite, hydrargillite, anatase), phosphates, sulphates, carbonates, clays, and allogenic detrital minerals (quartz, feldspars, zircon). The manganese minerals are scarce [8,25-28]. Several nodules and micronodules contain a solid detrital core and extensive Fe-(Mn) lamination [29], however, in some cases may be carbonate-rich [30]. Some pisoliths have internal cracks and veins, sometimes of a concentric nature. In extreme cases, as a result of the total discharge of mineral material from the nucleus, voids are especially noticeable [2].

Formation of Fe-rich precipitates is often associated with soil processes, such as bioaccumulation, the formation of weathering or illuvium horizons, adsorption on clay/organic particles or root exudation [22]. Some pisoliths are known also from pre-quaternary solid rocks and old soil horizons [11,16,17,27]. Nahon [22] describes pisoliths (pisolith concretions) as a result of the "glaebulisation" processes. The glaebulisation is a phenomenon of local dissolution of primary components and in situ crystallization of new minerals, mainly due to the iron remobilization and dilution. The final product of these processes are cracks and fissures as septarian shapes [31].

\section{Study Area}

The Roztoka Odrzańska is a small intermixing water basin of the Odra river mouth and Szczecin Lagoon, located around $20 \mathrm{~km}$ north from the city of Szczecin, NW Poland (Figure 1). It covers the area of $26.3 \mathrm{~km}^{2}$, has a length of $9 \mathrm{~km}$, a width of $1.1 \mathrm{~km}$ in the southern part (up to $5.7 \mathrm{~km}$ in the central part) and an average depth of $3.5 \mathrm{~m}$. The middle part of the Roztoka Odrzańska is cross-cut by the artificially created fairway of approximately $12 \mathrm{~m}$ of depth [32].

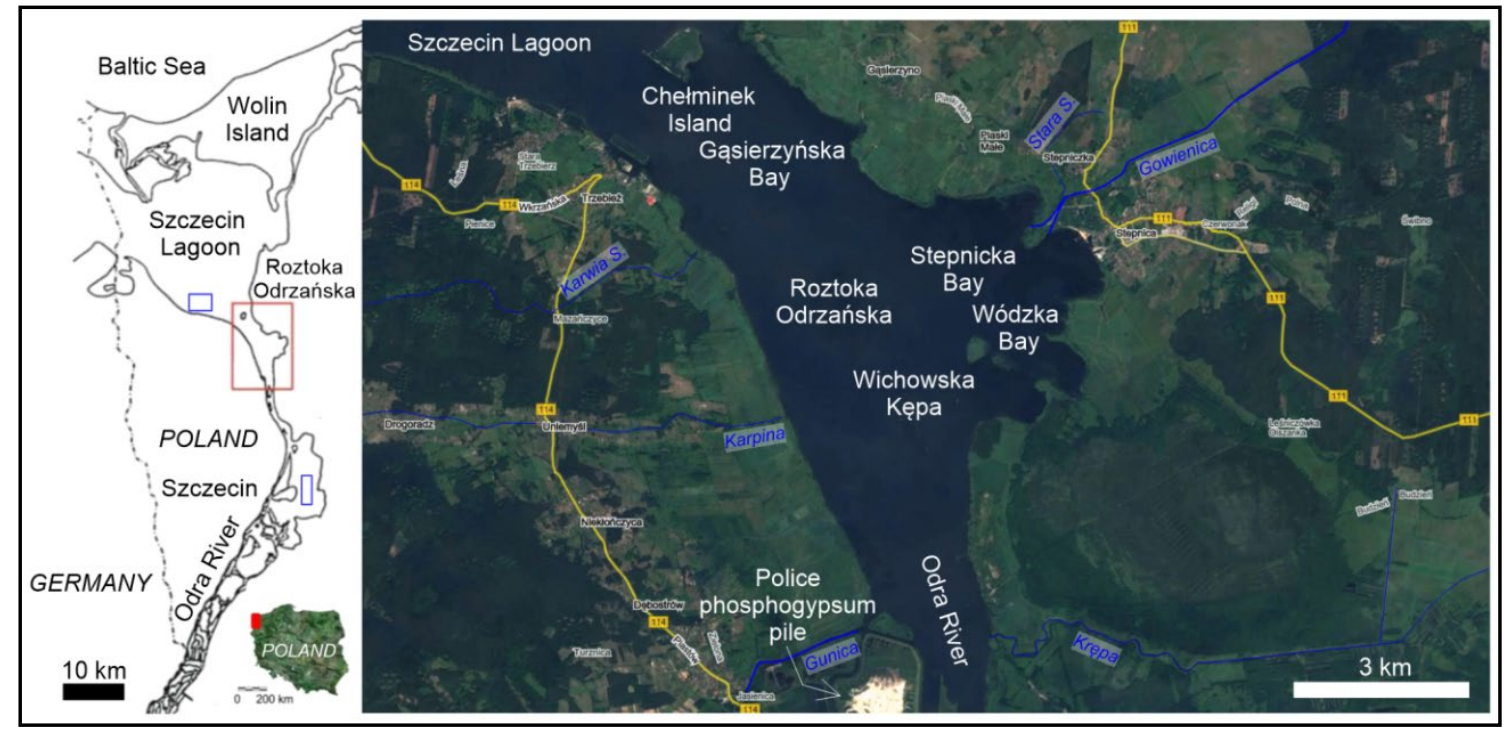

Figure 1. Location of the study area. The Roztoka Odrzańska is marked by a red rectangle; blue rectangles show sampling stations on the Dabie Lake and the Szczecin Lagoon, where previously non-described reference material was collected ([32,33]; slightly modified).

The area of investigation is a subject of complex hydrological processes, such as (i) exchange and intermixing of sea with freshwater, where the marine inflow can reach even up to $100 \mathrm{~km}$ inland; (ii) a complicated river channel system, with dense net of irrigation canals; (iii) significant water level changes, related mainly to windy storms and baric wave surges of the Baltic Sea [32,34].

The Roztoka Odrzańska is strongly affected by anthropogenic impacts, mainly related to industrial and agricultural contamination of surface water and sediments by heavy metals and biogenic compounds. Several anthropogenic forms in the area adjacent to the Roztoka Odrzańska are distinctive, including flood embankments, water dikes, and irrigating canals. On the west bank of the Odra River, the large pile of phosphogypsum, with a height of about $20 \mathrm{~m}$ was created through the industrial 
activity of the chemical fertilizers industry in Police (Figure 1). This is the main source of water suspended phosphorus in the area.

The study area was shaped during the last glaciation and postglacial period. The Holocene sediments dominate and are represented mainly by diluvial tills, sands, silty sands and peat bogs sediments. The lowest parts of terrain along the Odra River valley are covered with organic deposits (peats and peaty muds). The river flood plains and peat bogs surround the water body mainly from the east and west. Peat outcrops occur at heights up to $1 \mathrm{~m}$ a.s.l., in some cases even higher, forming in the small river valleys and incisions, even at an altitude up to $5 \mathrm{~m}$ a.s.l. Peats form mainly low bogs and, less frequently, high bogs [35] (Figure 2a).

The local river-flood plains rise up $20 \mathrm{~m}$ a.s.l. and were created as a result of the slow water outflow due to the melting of "dead ice" during the last glaciation. Deglaciation processes changed the water regime and induced the accumulation of sediments at the terraces of different heights. The plains are separated with numerous aeolian forms, depressions and narrow valley incisions [35].

There are several small rivers, bays, and islands located in the study area (Figure 1). The rivers are often connected with each other, and with the Odra River, by a complex of irrigation canals, discharging mostly to the Roztoka Odrzańska and Stepnicka Bay. The anthropogenic Chełminek Island was formed as a result of the dredging of the water track from Szczecin to Świnoujście and dumping the excavated sedimentary material, which started in 1889 [36].

The mean level of surface water outflow of the Odra river section nearby the Roztoka Odrzańska is very small and equals to $0.0015 \%$ o [37]. The average volume of water discharging from the Odra to the Roztoka Odrzańska is around $500 \mathrm{~m}^{3} / \mathrm{s}$ [38]. The rip crevices have definitely also had a great impact on the changes of the water level in the Odra River system [39].

The surface and bottom water of the Roztoka Odrzańska are usually warmer by 0.5 to $1.0^{\circ} \mathrm{C}$ and 0.1 to $0.4{ }^{\circ} \mathrm{C}$, respectively, compared to the Szczecin Lagoon. The salinity is around 0.1 to $0.4 \%$ ond is lower than in the Szczecin Lagoon. The water oxidation is worse than in the Szczecin Lagoon and drops from 8 to $5 \mathrm{mg} / \mathrm{dm}^{-3} \mathrm{O}_{2 \text { (dis.) }}$ at the bottom. The water is also slightly less alkaline compared to the Szczecin Lagoon, and reaches 7.15 to $8.8 \mathrm{pH}$ [40].

The general chemical quality of surface water is bad or below good. The groundwater show highly elevated concentrations of $\mathrm{Fe}^{2+}, \mathrm{Mn}^{2+}$ and $\mathrm{Cl}^{-}$[41]. The total groundwater mineralization in the area of Stepnica and Police is high and ranges from 300 to $3000 \mathrm{mg} / \mathrm{dm}^{3}$. The dominating macro-components are $\mathrm{Ca}^{2+}$ (23\% to $\left.40 \% \mathrm{mval}\right), \mathrm{HCO}_{3}{ }^{-}(23 \%$ to $50 \% \mathrm{mval})$, and $\mathrm{Cl}^{-}$. The contents of $\mathrm{Mg}^{2+}$ and $\mathrm{SO}_{4}{ }^{2-}$ are generally lower, $2-10 \% \mathrm{mval}$ and 5-25\% mval, respectively. The phosphorus content range is high, usually $0.7-3.0 \mathrm{mg} / \mathrm{dm}^{3}$, and in some areas even higher. The $\mathrm{Zn}^{2+}$ content is usually between 0.99 and $5.00 \mathrm{mg} / \mathrm{dm}^{3}$.

The $\mathrm{pH}$ of the groundwater is between 6 and 7. The total iron concentrations are high, usually around 0.50 to $5.50 \mathrm{mg} / \mathrm{dm}^{3}$. The $\mathrm{Mn}^{2+}$ content is usually around $0.1 \mathrm{mg} / \mathrm{dm}^{3}$. The dissolved silica $\mathrm{SiO}_{2}$ is between 16.3 and $22.9 \mathrm{mg} / \mathrm{dm}^{3}$, and only in the northern part (around Stepnica and Gasierzyno) these values are elevated $\left(>29.5 \mathrm{mg} / \mathrm{dm}^{3}\right)$. The $\mathrm{Al}^{3+}$ concentration is often $<0.3 \mathrm{mg} / \mathrm{dm}^{3}$. The total hardness of the groundwater spans from 400 to $600 \mathrm{mg} \mathrm{CaCO}_{3} / \mathrm{dm}^{3}$ [42].

The contamination of surface water and sediments in the Roztoka Odrzańska is well documented and associated with anthropogenic impacts. The Odra River flowing by the Roztoka Odrzańska, transports contaminants from the south, from the heavily urbanized areas. The main local areas of pollution are located nearby the harbor of Szczecin and the chemical factory in Police.

In the bottom sediments, pollution accumulates mainly due to wastewater input, mostly industrial and municipal, and less from surface runoff. The concentration of pollutants in the bottom sediments is mainly related to the river transport mechanisms, sorption potential of fine-grained and organic-rich sediments or physical and chemical properties of sediments, such as solubility, $\mathrm{pH}$, and redox potential [43].

The surface sediments from the local rivers are characterized by mean variable concentration of: $\mathrm{Ca}(0.6-1.23 \%), \mathrm{Mg}(0.03-0.08 \%), \mathrm{Fe}(0.87-0.96 \%), \mathrm{Mn}(229-1287 \mathrm{ppm}), \mathrm{P}(0.08-0.1 \%), \mathrm{S}(0.047-0.193 \%)$, 
and $\mathrm{Zn}$ (28-37 ppm). The mean contents of metals in the Szczecin Lagoon are 1.67\% of Ca, 1.18\% of Fe, $0.05 \%$ of $\mathrm{Mg}, 212 \mathrm{ppm}$ of $\mathrm{Mn}, 0.027 \%$ of P, $0.041 \%$ of S, and $247 \mathrm{ppm}$ of $\mathrm{Zn}$. Sediments show traces of $\mathrm{Cr}$ in a range of $2-4 \mathrm{ppm}$ [44]. The detailed geochemical data of surface sediments and water from the area of Roztoka Odrzańska/small local rivers are presented in Table 1.

The Roztoka Odrzańska sediments are mainly gyttja or sapropel muds with more than $50 \%$ of the silty-clayey fraction (Figure $2 b$ ). The iron content and heavy metals contamination (Figure 2c,d) is especially high in the uppermost $25 \mathrm{~cm}$ of sediments and includes elevated values of cadmium, copper, zinc, lead, cobalt, and mercury [32]. The sediments show also high contents of magnesium, potassium, and manganese [45]. Additionally, the increased concentration of heavy metals was detected in the shells of mollusks [46].

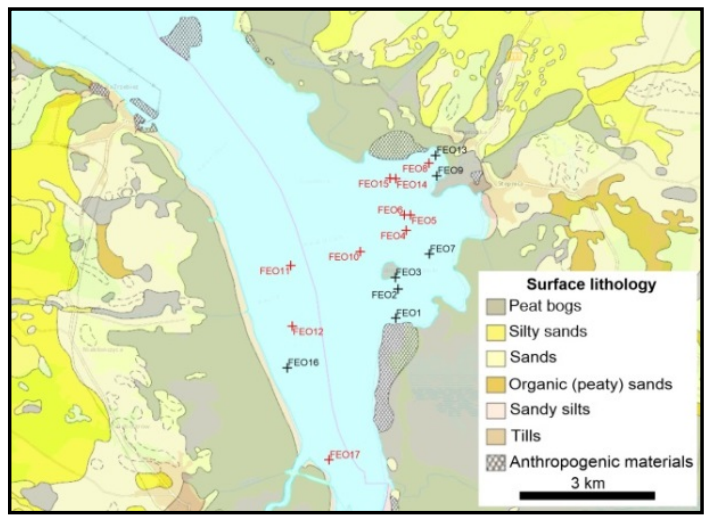

(a)

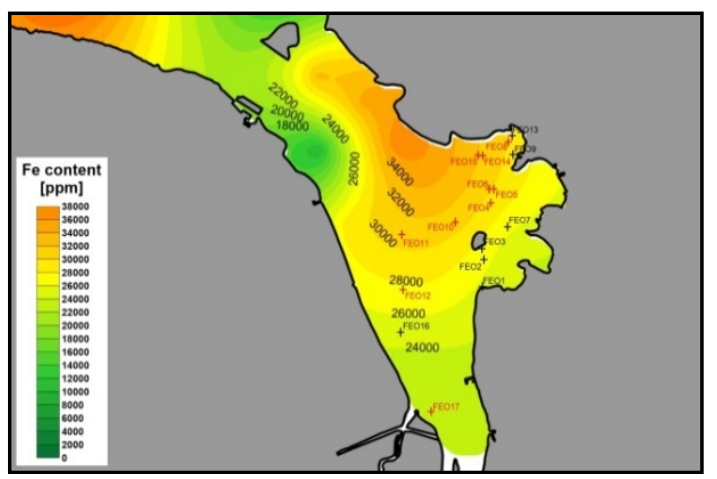

(c)

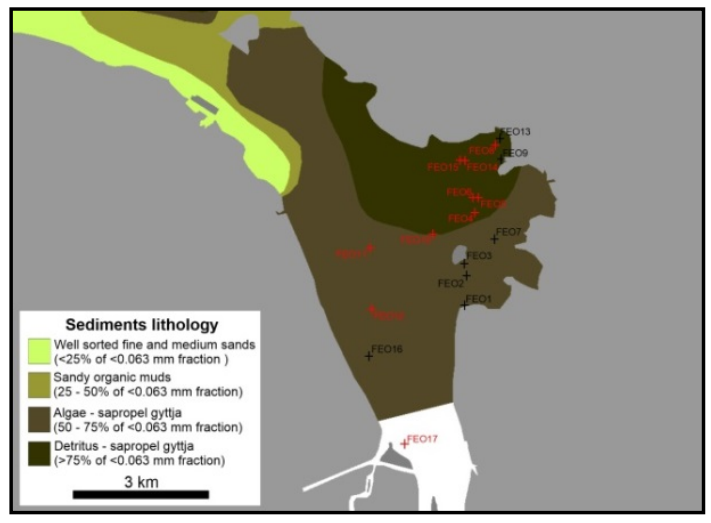

(b)

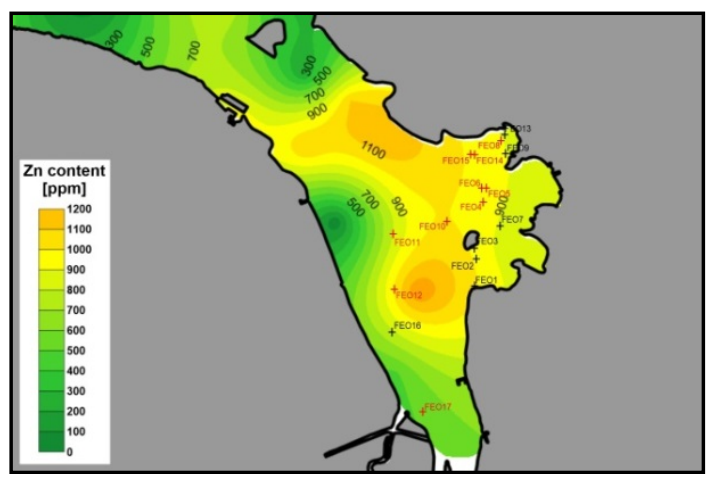

(d)

Figure 2. Location of the study area: (a) lithogenetic map of Poland; source [47]; (b) surface sediments map of the Roztoka Odrzańska; (c) map of iron content distribution in the surface sediments of the Roztoka Odrzańska; (d) map of zinc content in the surface sediments of the Roztoka Odrzańska. Red sampling sites mean sediments where pisolith nodules are found; black dots are stations without micronodules. 
Table 1. Selected geochemical parameters of surface sediments and water from the area of Roztoka Odrzańska; after [44].

\begin{tabular}{|c|c|c|c|c|c|c|c|c|c|c|}
\hline Surface Sediments & Al & $\mathrm{Ca}$ & $\mathrm{Mg}$ & $\mathbf{F e}$ & $\mathbf{P}$ & $\mathbf{S}$ & Mn & $\mathrm{Cr}$ & $\mathrm{Zn}$ & $\mathrm{pH} /$ cond. \\
\hline & \multicolumn{6}{|c|}{$(\%)$} & \multicolumn{3}{|c|}{ (ppm) } & $(\mathrm{mS} / \mathrm{cm})$ \\
\hline Gunica & 0.12 & 1.23 & 0.08 & 0.87 & 0.085 & 0.047 & 283 & 2 & 33 & - \\
\hline Gowienica & 0.14 & 0.60 & 0.04 & 0.95 & 0.080 & 0.073 & 1287 & 2 & 28 & - \\
\hline Krępa & 0.19 & 0.79 & 0.03 & 0.96 & 0.100 & 0.193 & 229 & 2 & 37 & - \\
\hline Odra & 0.28 & 1.27 & 0.09 & 1.38 & 0.101 & 0.134 & 634 & 10 & 152 & - \\
\hline Szczecin Lagoon & 0.08 & 0.94 & 0.05 & 0.28 & 0.027 & 0.041 & 212 & 2 & 60 & - \\
\hline \multirow[t]{2}{*}{ Surface Water } & Al & $\mathrm{Ca}$ & $\mathrm{Mg}$ & $\mathrm{Fe}$ & $\mathrm{SiO}_{2}$ & $\mathrm{SO}_{4}$ & Mn & $\mathrm{Cr}$ & $\mathrm{Zn}$ & $\mathrm{pH} /$ cond. \\
\hline & \multicolumn{6}{|c|}{ (ppm) } & \multicolumn{3}{|c|}{$(\mathrm{ppb})$} & $(\mathrm{mS} / \mathrm{cm})$ \\
\hline Gunica & $<0.05$ & 116 & 9.7 & 0.26 & 12.5 & 142 & 369 & $<4$ & $<5$ & $7.5 / 1.54$ \\
\hline Gowienica & $<0.05$ & 75 & 5.2 & 0.36 & 9.6 & 65 & 217 & $<4$ & $<5$ & $7.2 / 0.51$ \\
\hline Krępa & 0.11 & 51 & 3.2 & 0.44 & 11.0 & 59 & 172 & $<4$ & $<5$ & $4.1 / 0.44$ \\
\hline Odra & $<0.05$ & 75 & 12.1 & 0.04 & 3.5 & 105 & 75 & $<4$ & 6 & $7.9 / 0.78$ \\
\hline Szczecin Lagoon & $<0.05$ & 92 & 14.8 & 1.00 & 13.1 & 86 & 247 & $<4$ & $<5$ & $8.4 / 2.05$ \\
\hline
\end{tabular}

\section{Materials and Methods}

The sediments containing pisolith nodules were collected from the eastern part of Roztoka Odrzańska, Odra river, northern Poland. The samples were taken directly from the water, using a Van Veen sludge trap deployed from a catamaran "Szuwarek." To determine whether the sediments contain some micronodules, samples were flushed using a $4 \mathrm{~mm}$ sieve. The shells and plant debris was removed using a $500 \mu \mathrm{m}$ sieve. The material remained in the $500 \mu \mathrm{m}$ sieve was described and pisolith nodules were separated. Photographs were taken using a Zeiss Stereo Discovery.V20 stereoscopic microscope with PlanApo S1.0 lens, smooth adjustment, Canon EOS 500D camera and AxioVision (Rel. 4.8. Edition) software. Sediment sampling, preparatics, and photographs were taken at the Institute of Marine and Environmental Sciences, University of Szczecin, Poland.

Representative pisolith nodules were analyzed using the SEM-energy dispersive x-ray (EDX) method at the Polish Geological Institute-National Research Institute, Holy Cross Mts. Branch in Kielce, Poland. Hitachi TM 3030 scanning electron microscope, equipped with the Thermo EDS detector Noran System 7 was used. An acceleration voltage of $15.0 \mathrm{kV}$ was applied. Additionally, samples were covered by carbon coating using the Cressington 108 carbon sprayer. For this reason, and also due to samples immerse in epoxide resin, the total $C$ content was omitted in the analysis. In the case of $>10 \%$ of carbon, the results were included in the chemical data. The results obtained allowed a chemical recognition of minerals. The structural water content $\mathrm{H}_{2} \mathrm{O}^{-}$was calculated from stoichiometry. The chemical data were the basis for the calculation of metal ratios, such as $\mathrm{Fe} / \mathrm{Mn}, \mathrm{P} / \mathrm{Fe}$, $\mathrm{Ca} / \mathrm{Mg}$, Si/Al, or Fe/S.

Additionally, few crushed pisoliths were analyzed using XRD (Faculty of Chemical Technology and Engineering, West Pomeranian University of Technology, Szczecin). The pulverized nodules were investigated using a PANanalytical Empyrean II diffractometer. The $\mathrm{CuK} \alpha_{1}(1.540598 \AA)$ radiation, the voltage of $35 \mathrm{kV}$, and beam intensity of $30 \mathrm{~mA}$, measuring angles range $5-70^{\circ} 2 \theta$ and step of $0.02^{\circ} / 2 \mathrm{~s}$ were applied. The device was equipped with a graphite monochromator and PIXcel 3D strip detector. In addition, the Ni- $\beta$ filter and spinner (1 sample rotation per 16s) were implemented.

The qualitative and quantitative identification of minerals was made using the Match! 3 software and the COD-Inorg REV214414 database (state of records on 29 March 2019) [48]. The number of mineral phases was estimated with the Rietveld refinement and FullProf software.

As the reference material for the Odra River hydrological system and analyzed pisolith nodules, we investigated and described previously unknown nodules from the Dabie Lake and middle part of the Szczecin Lagoon. These samples were collected also directly from the water in 2009-2011. Additionally, we compared results obtained with archival data of the lake, lacustrine and riverine 
nodules, bog ores, selected P- and Fe-rich minerals, siderite ores, organic sediments, polymetallic nodules, and Baltic Sea nodules (Appendix A).

\section{Results}

The loose pisolith micronodules were found in the surface sediments of the Roztoka Odrzańska within 10 of 17 sampling stations (Figure 2a). The material was found in the gyttja and sandy gyttja/sandy sapropel muds, including also the shells of Dreissena polymorpha, fragments of plants, quartz grains, scales, skeletal remnants of fish, spouses, and peat fragments.

\subsection{General Description}

The two major textural types of pisolith nodules were identified: (i) soft and porous, spherical, 0.2 to $0.5 \mathrm{~mm}$ in diameter, covered only by a thin rust-yellowish cortex, composed of weathered hematite or limonite, disintegrating even after a slight touch, with no distinctive geometric internal texture, nuclei, and layering (Figure 3a-d); (ii) solid, with well-developed cortex, concentric layering and nuclei, in few cases with the septarian-type cracks inside the nucleus (Figure 4a-f). The type (i) was identified in nine samples and type (ii) only in one (FEO8).

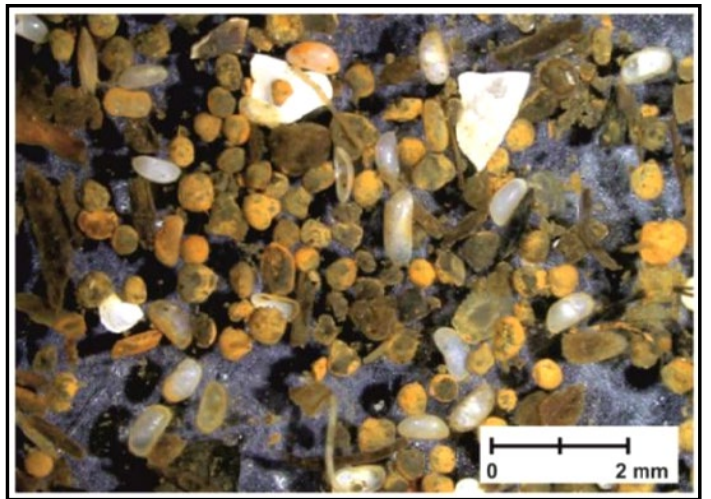

(a)

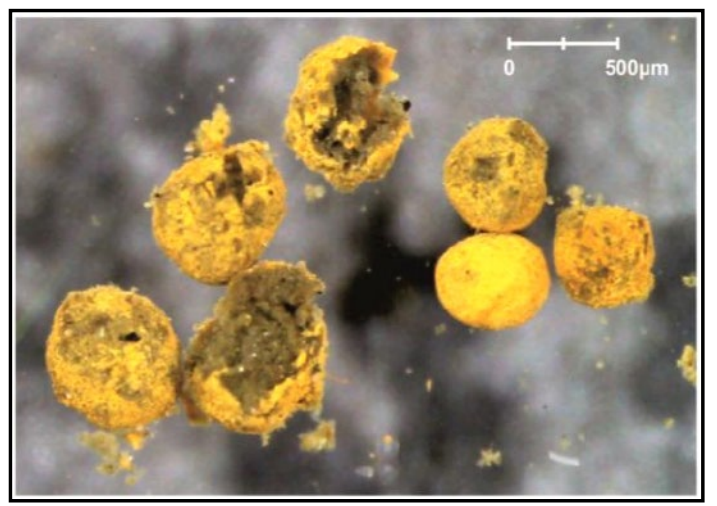

(c)

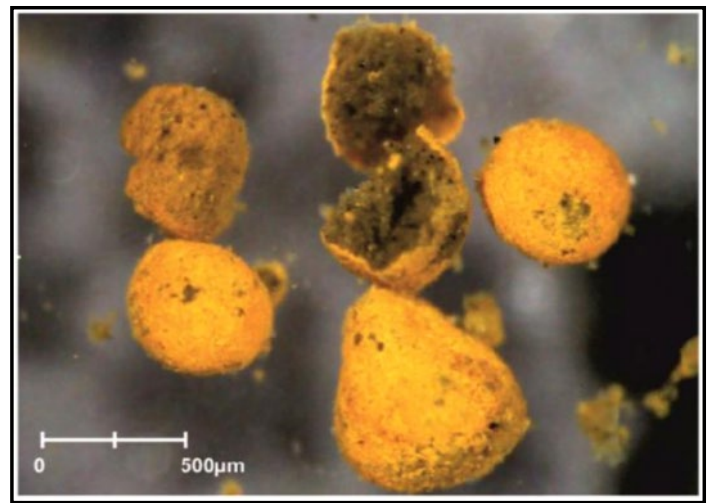

(b)

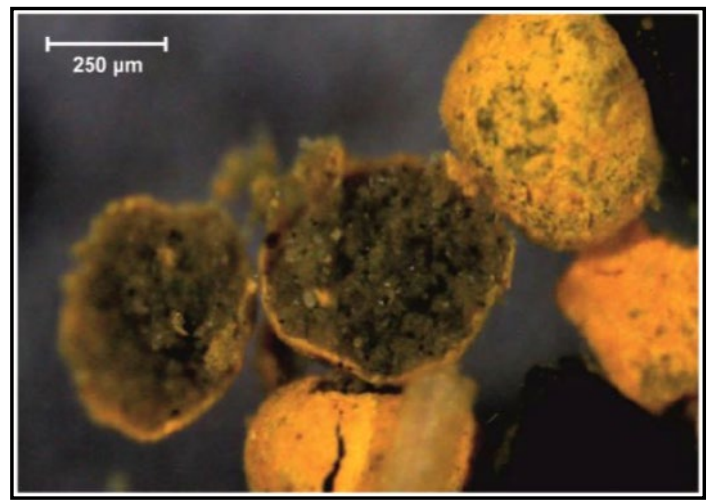

(d)

Figure 3. Examples of loose, soft and earthy spherical micronodules collected from the FEO4 sampling site $(\mathbf{a}-\mathbf{d})$. The interior shows a highly porous texture, composed mainly of goethite, with traces of phosphates, and carbonates. The thin yellowish cortex developed as an oxidation layer composed of limonite or hematite.

The greatest amount of best-preserved pisolith micronodules were found in the FEO8 sample, where we counted 165 whole nodules, 19 broken, and 7 halves. Specimens varied of size from 0.5 to $2 \mathrm{~mm}$ and showed spherical or oval forms. Some nodules were broken and cracked, mostly due to the drying and loose of water due to the dehydration of external layers (Figure 4). In some cases, 
blueish oxidized surfaces of phosphate minerals were identified (Figure 4e). Almost all of the broken micronodules showed the presence of a nucleus, mainly of detrital origin, such as quartz or feldspar (Figure 4f).

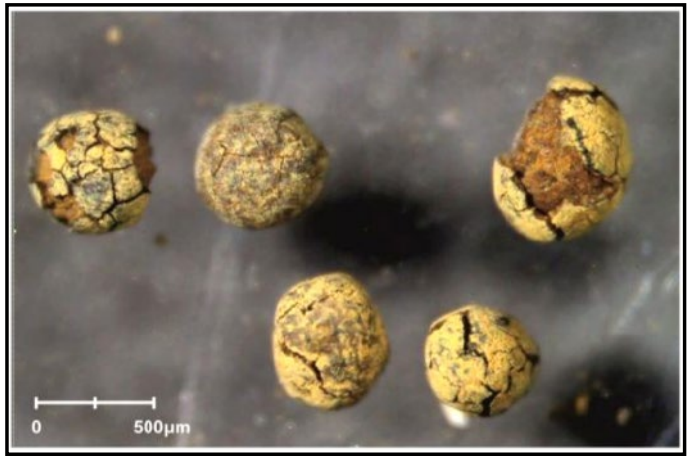

(a)

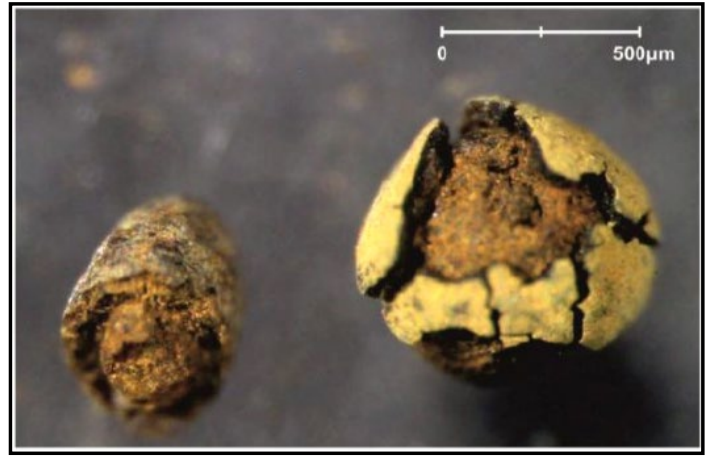

(c)

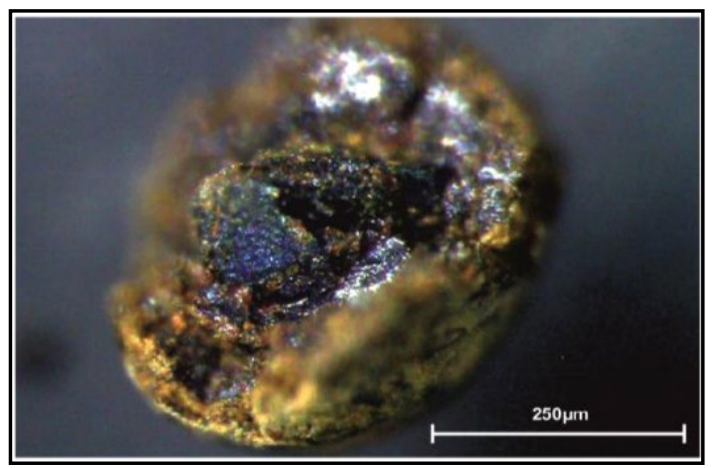

(e)

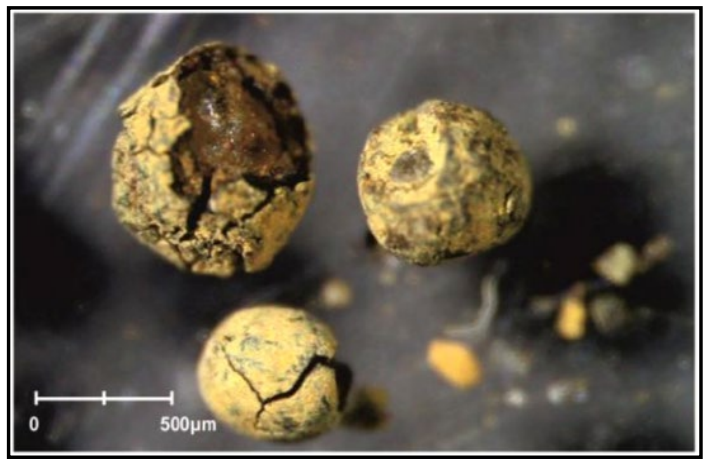

(b)

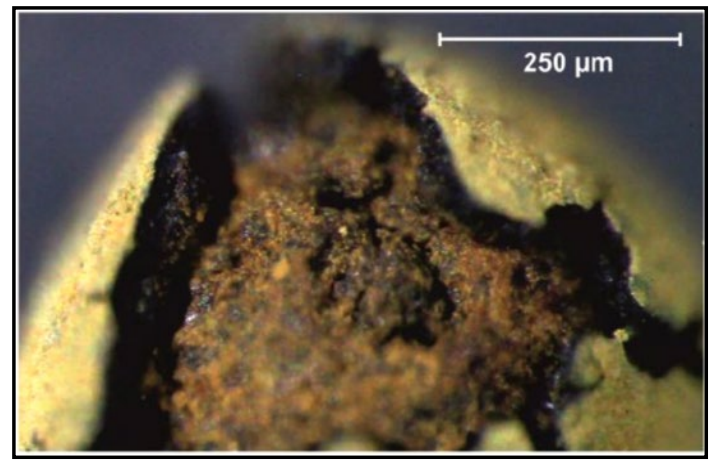

(d)

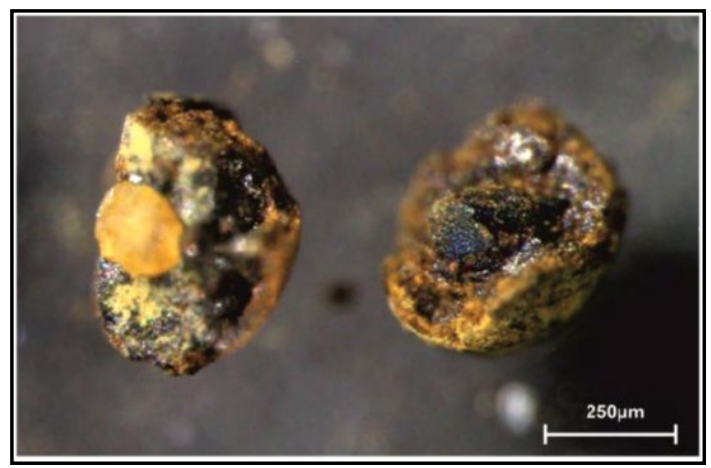

(f)

Figure 4. Examples of loose, solid spherical micronodules collected from the FEO8 sampling site. The thin and radially crushed yellowish cortex developed as an oxidation layer built of limonite and hematite. Interior shows the presence of solid authigenic nucleus (massive iron oxyhydroxides or siderite; (a-e) or detrital one (f). In some cases, septarian-type cracks were observed.

\subsection{XRD}

According to the XRD bulk powder analysis of selected micronodules (Figure 5), several minerals were identified (Table 2). Among them, the Fe-hydroxides and Fe-oxides, typical of aerobic environments, dominate:

1. goethite showing several but non-distinctive chemical substitution [49];

2. proto-hematite [50]; 
3. hematite with isomorphic substitutions (contaminated) [51];

4. lepidocrocite [52];

5. ferrihydrite [53];

6. traces of native Fe [54].

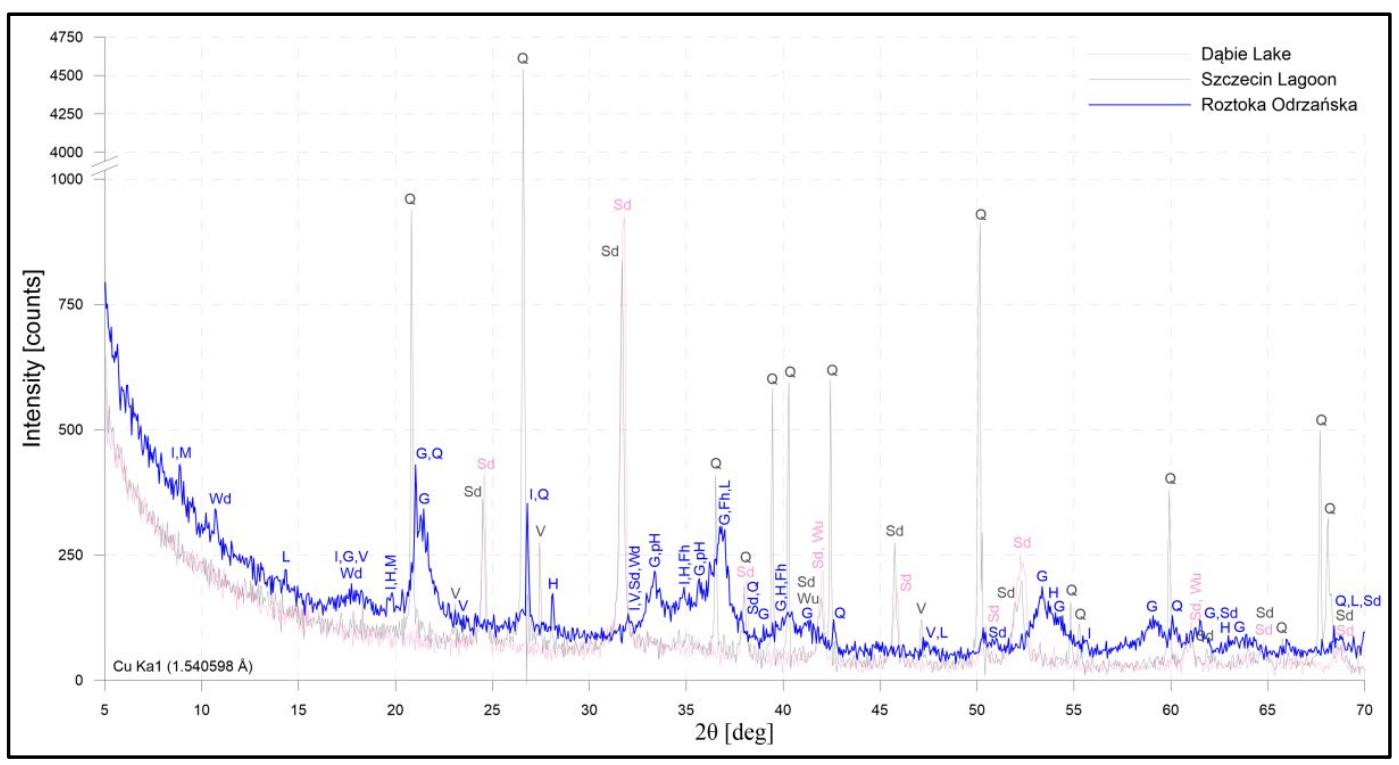

Figure 5. Representative XRD powder diffractograms of the FEO8 sample from the Roztoka Odrzańska, and reference nodules from the Dabie Lake and Szczecin Lagoon. The identified minerals are Q-quartz, G-goethite, $\mathrm{H}$-hematite, $\mathrm{pH}$-proto-hematite, L-lepidocrocite, Fh-ferrihydrite, V-vivianite (metavivianite), Sd-siderite, I-illite, M-montmorillonite (Fe-smectite), Wd-woodwardite (Zn-woodwardite), and $\mathrm{Wu}$-wüstite.

In the group of phosphates, the hydrated Fe-phosphate in a type of metavivianite $\left(\mathrm{Fe}^{3+}\right)$ and vivianite $\left(\mathrm{Fe}^{2+}\right)$, typical for oxygen-rich environments $[55,56]$ was identified. Additionally, the $\beta$-quartz was identified and traces of Fe-carbonates, mainly in siderite type [57]. Clay minerals include illite and Fe-smectite, with the domination of illite [58,59].

The chemically most complex are mixed and hydrated sulfates, carbonates, or sulfo(carbonates), best matching for woodwardite and zincwoodwardite [60,61]. These minerals are products of decomposition of, most likely, anthropogenic products, such us industrial dust or trails. Their presence was confirmed by the SEM-EDX analysis.

The XRD analysis indicated the presence of feldspar, zircon and other less frequent debris minerals found during SEM-EDX was not confirmed. The traces of decomposing chromium minerals, most likely weathering spinels or some anthropogenic products, were not visible.

The XRD data of Roztoka Odrzańska pisolith nodules, compared to micronodules from the Dabie Lake and Szczecin Lagoon, indicate significant differences (Table 2). The Szczecin Lagoon sample is dominated by quartz $(78.9 \%)$ and siderite $(18.5 \%)$, with traces of vivianite or metavivianite $(1.8 \%)$, and wüstite $(<1 \%)$. The nodules from the Dabie Lake are dominated by Mn-substituted siderite $(88.4 \%)$ [62], with admixture of quartz $(10.0 \%)$, traces of wüstite $(1.5 \%)$ [63], and native iron $(<1 \%)$. 
Table 2. The XRD data of the FEO8 bulk micronodules from the Roztoka Odrzańska, Odra River, NW Poland. Additionally, the reference nodules from the Dabie Lake and Szczecin Lagoon are included.

\begin{tabular}{|c|c|c|c|}
\hline \multirow[b]{2}{*}{ Identified Minerals with Theoretical Chemical Formula } & \multicolumn{3}{|c|}{ Content $(\%)$} \\
\hline & $\begin{array}{l}\text { Roztoka O. } \\
\text { (FEO8) }\end{array}$ & Dąbie Lake & $\begin{array}{c}\text { Szczecin } \\
\text { Lagoon }\end{array}$ \\
\hline quartz $\beta-\mathrm{SiO}_{2}$ & 7.0 & 10.0 & 78.9 \\
\hline goethite $\alpha-\mathrm{FeO}(\mathrm{OH})$ & 29.8 & - & - \\
\hline hematite $\mathrm{Fe}_{2} \mathrm{O}_{3}$ & 6.5 & - & - \\
\hline wüstite $\mathrm{FeO}$ & - & 1.5 & traces $^{1}$ \\
\hline proto-hematite $\mathrm{Fe}_{1.9} \mathrm{H}_{0.06} \mathrm{O}_{3}$ & 6.4 & - & - \\
\hline lepidocrocite $\gamma-\mathrm{FeO}(\mathrm{OH})$ & 2.7 & - & - \\
\hline ferrihydrite $\left(\mathrm{Fe}^{3+}\right)_{2} \mathrm{O}_{3} \cdot 0.5 \mathrm{H}_{2} \mathrm{O}$ & 5.5 & - & - \\
\hline native iron $\mathrm{Fe}$ & traces ${ }^{1}$ & traces ${ }^{1}$ & - \\
\hline vivianite-metavivianite & & & \\
\hline $\mathrm{Fe}^{2+} \mathrm{Fe}^{2+}{ }_{2}\left(\mathrm{PO}_{4}\right)_{2} \cdot 8 \mathrm{H}_{2} \mathrm{O}$ & 9.7 & - & 1.8 \\
\hline $\mathrm{Fe}^{3+}{ }_{2}\left(\mathrm{PO}_{4}\right)_{2}(\mathrm{OH})_{2} \cdot 6 \mathrm{H}_{2} \mathrm{O}$ & & & \\
\hline siderite $\mathrm{FeCO}_{3}$ & 4.3 & $88.4^{2}$ & 18.5 \\
\hline illite $\mathrm{K}_{0.6-0.85} \mathrm{Al}_{2}(\mathrm{Si}, \mathrm{Al})_{4} \mathrm{O}_{10}(\mathrm{OH})_{2}$ & 26.1 & - & - \\
\hline $\begin{array}{l}\text { montmorillonite (Fe-smectite) } \\
\left(\mathrm{CaO}_{0.5}, \mathrm{Na}\right)_{0.3} \mathrm{Fe}^{3+}{ }_{2}(\mathrm{Si}, \mathrm{Al})_{4} \mathrm{O}_{10}(\mathrm{OH})_{2} \cdot \mathrm{nH}_{2} \mathrm{O} \\
\text { woodwardite-zincwoodwardite }\end{array}$ & 1.4 & - & - \\
\hline $\mathrm{Cu}_{4} \mathrm{Al}_{2}\left(\mathrm{SO}_{4}\right)(\mathrm{OH})_{12} \cdot 2-4\left(\mathrm{H}_{2} \mathrm{O}\right)$ & traces $^{1}$ & - & - \\
\hline$\left[\mathrm{Zn}_{1-\mathrm{x}} \mathrm{Al}_{\mathrm{x}}(\mathrm{OH})_{2}\right]\left[\left(\mathrm{SO}_{4}\right)_{\mathrm{x} / 2}\left(\mathrm{H}_{2} \mathrm{O}\right)_{\mathrm{n}}\right]$ & & & \\
\hline
\end{tabular}

${ }^{1}$ Minerals with content $<1 \% ;{ }^{2}$ Around $10 \%$ of siderite show increased contents of Mn (potential admixtures of rhodochrosite).

\subsection{SEM-EDX Analysis}

The SEM-EDX analysis reveals concentric textures and a frequent presence of solid nuclei, admixtures of detrital material, such as quartz, K-feldspar or zircon, remnants of chromium minerals, and others (Figure 6a-e). Cortex is composed mainly of Fe-hydroxides in a type of goethite, with smaller content of hematite. Hematite was discovered mainly as an oxidation layer developed in a form of coating covering nuclei, or a very thin external layer.

According to the results of the SEM-EDX chemical analysis (Table 3), the individual pisoliths are dominated by Fe-oxyhydroxides in a type of goethite (or lepidocrocite). The identified Fe-hydroxides show a low structural deficiency in $\mathrm{Fe}^{3+}(\sim 9 \%)$, being substituted mainly by $\mathrm{Si}, \mathrm{P}, \mathrm{Al}$, and $\mathrm{Ca}$. Additionally, vacancies of $\mathrm{Mn}, \mathrm{Mg}, \mathrm{S}, \mathrm{V}, \mathrm{Zn}$, and $\mathrm{F}$ were observed. The mean calculated $\mathrm{H}_{2} \mathrm{O}^{-}$content is $13.83 \%$. The hematite was identified as a minor component and shows greater vacancies of $\mathrm{Si}, \mathrm{P}$, $\mathrm{Ca}, \mathrm{Al}$, and S. Similarly to goethite, hematite indicates phosphatization and traces of $\mathrm{S}$. The nuclei of analyzed pisoliths are composed of some debris minerals, like quartz, K-feldspar, zircon, Cr-spinel and non-defined Fe-Cr-Si phase. Besides this, some mixed Zn-sulfo(carbonates), which show some chemical similarities to woodwardite or $\mathrm{Zn}$-woodwardite, are found. Woodwardite and its $\mathrm{Zn}$-rich analog are often associated as a by-product of industrial materials.

All identified Fe-hydroxides show higher than theoretical content of structural water, which may be evidence of chemical decomposition processes occurring in the water environment. Additionally, the higher vacancy and substitution by alkali or $\mathrm{Si}+\mathrm{Al}$ indicates pisolith formation in the sedimentary environment. 


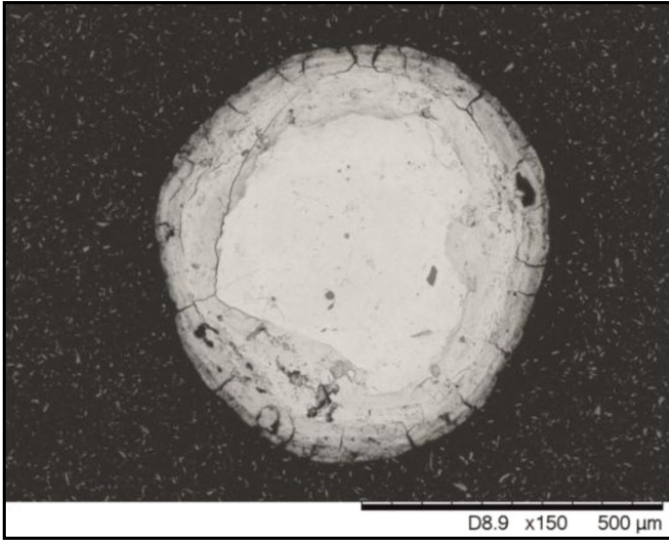

(a)

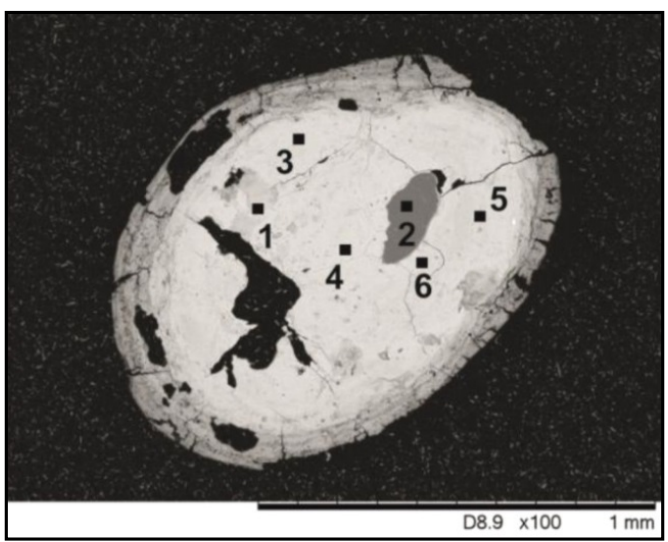

(c)

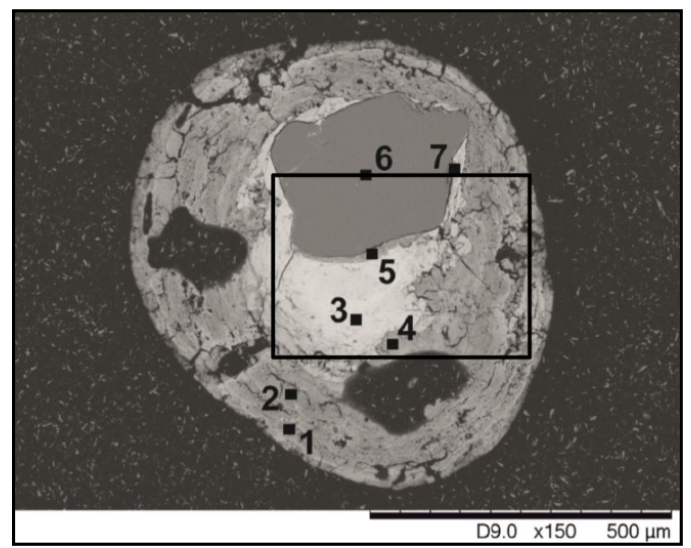

(e)

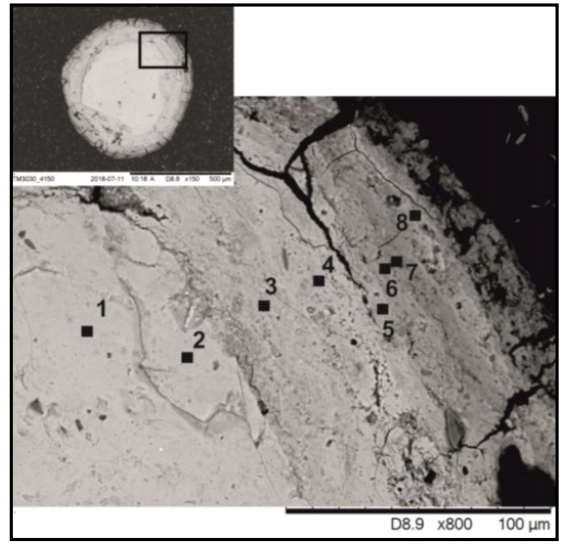

(b)

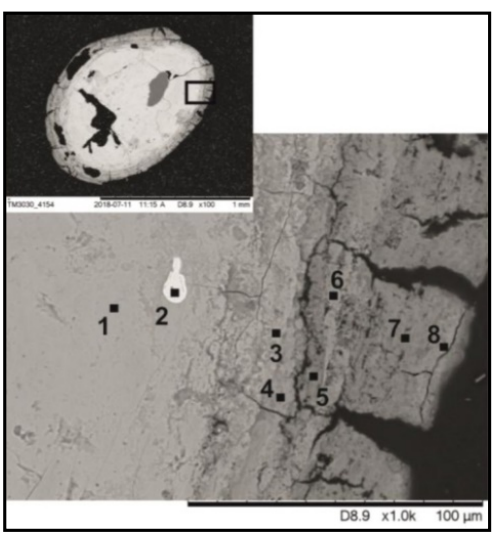

(d)

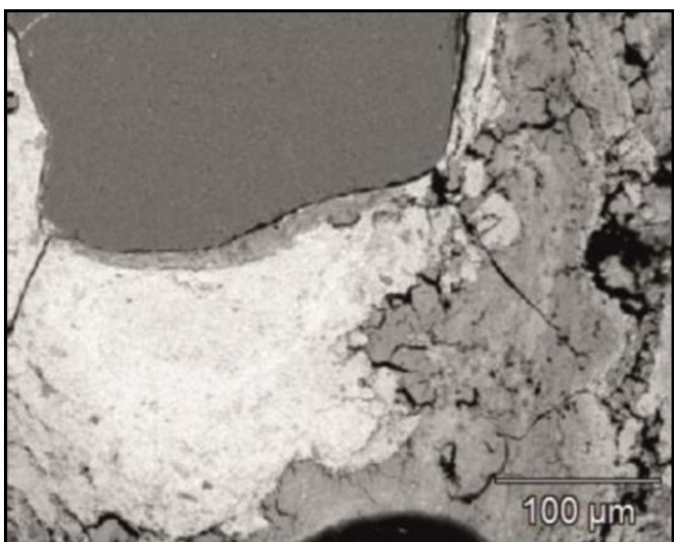

(f)

Figure 6. Representative SEM photos and energy dispersive x-ray (EDX) data points of pisolith nodules from the Roztoka Odrzańska: (a) round micronodule with solid detrital quartz nuclei (1), surrounded by goethite coating $(\mathbf{b} ; 2-8)$; slight $\mathrm{Si}$ and Ca content increase towards crushed edges and highest Fe contents in points 6-7; (c) oval pisolith nodule with quartz debris (2) and goethite core (1, 3-6); empty spaces after loose grains and subtle internal crushes; more distinctive laminae-like external layer; (d) laminated and radially crushed external layer composed of goethite $(1,4,6,8)$, hematite (3 and 7$)$ and detrital zircon (2); intermixtures of non-identified Zn-rich sulpho(carbonates) (5); (e) micronodule with distinctive two layers composed of goethite (1-5), detrital quartz (6) and non-identified Cr-rich minerals, probably remnants of Cr-rich spinels or Cr-phyllosilicates (7); zone of increase in Fe content and decrease with $\mathrm{H}_{2} \mathrm{O}^{-}$and $\mathrm{Al}$ (1 to 5); (f) zoom on transition of quartz nucleus and goethite. 
Table 3. Mean SEM-EDX chemical data of selected pisolith micronodules from the Roztoka Odrzańska, Odra River, NW Poland.

\begin{tabular}{|c|c|c|c|c|c|c|c|}
\hline & $\begin{array}{c}\text { Fe-hydroxides } \\
\mathrm{Fe}^{3+}-\mathrm{H}_{2} \mathrm{O}^{-} \\
\mathrm{N}=43\end{array}$ & $\begin{array}{c}\text { Hematite } \\
\mathrm{Fe}^{3+}-\mathrm{O}_{2}{ }^{-} \\
\mathrm{N}=3\end{array}$ & $\begin{array}{c}\text { K-Feldspar } \\
\qquad \begin{array}{c}\mathrm{N}=2\end{array}\end{array}$ & $\begin{array}{l}\text { Zircon } \\
\mathrm{N}=1\end{array}$ & $\begin{array}{c}\mathrm{Wdw} / \mathrm{Zn}-\mathrm{Wdw}{ }^{2} \\
\mathrm{Zn}^{2+}-\mathrm{CO}-\mathrm{H}_{2} \mathrm{O}^{-} \\
\mathrm{N}=2\end{array}$ & $\begin{array}{l}\mathrm{NI}^{3} \\
\mathrm{Fe}-\mathrm{Cr} \\
\mathrm{N}=3\end{array}$ & $\begin{array}{c}\mathrm{NI}^{3} \\
\text { Si-Cr-Fe } \\
\mathrm{N}=2\end{array}$ \\
\hline $\mathrm{SiO}_{2}$ & 4.95 & 7.93 & 57.69 & 23.15 & 4.97 & 10.06 & 53.18 \\
\hline $\mathrm{Al}_{2} \mathrm{O}_{3}$ & 0.76 & 0.69 & 18.27 & - & 0.73 & 0.19 & - \\
\hline $\mathrm{MgO}$ & 0.18 & - & - & - & - & - & - \\
\hline $\mathrm{CaO}$ & 2.35 & 2.91 & - & - & 1.73 & 1.54 & - \\
\hline $\mathrm{Na}_{2} \mathrm{O}$ & traces $^{1}$ & - & - & - & - & - & - \\
\hline $\mathrm{K}_{2} \mathrm{O}$ & - & - & 20.04 & - & - & - & - \\
\hline $\mathrm{MnO}$ & 0.35 & - & - & - & - & 0.52 & - \\
\hline $\mathrm{FeO}_{\mathrm{t}}$ & - & - & 4.01 & 5.03 & 24.58 & 72.17 & 3.61 \\
\hline $\mathrm{Fe}_{2} \mathrm{O}_{3}$ & 80.89 & 84.90 & - & - & - & - & - \\
\hline $\mathrm{Cr}_{2} \mathrm{O}_{3}$ & - & traces $^{1}$ & - & - & - & 4.68 & 15.60 \\
\hline $\mathrm{V}_{2} \mathrm{O}_{5}$ & traces ${ }^{1}$ & - & - & - & - & - & - \\
\hline $\mathrm{ZnO}$ & traces $^{1}$ & - & - & - & 11.94 & - & - \\
\hline $\mathrm{P}_{2} \mathrm{O}_{5}$ & 4.79 & 3.22 & - & - & 2.30 & 3.33 & 0.48 \\
\hline $\mathrm{ZrO}_{2}$ & - & - & - & 71.81 & - & - & - \\
\hline $\mathrm{SO}_{2}{ }^{-}$ & 0.23 & 0.35 & - & - & 9.27 & - & - \\
\hline $\mathrm{CO}_{2}^{-}$ & - & - & - & - & 22.67 & - & 23.13 \\
\hline $\mathrm{F}^{-}$ & traces $^{1}$ & - & - & - & - & - & - \\
\hline $\mathrm{H}_{2} \mathrm{O}^{-}$ & 13.83 & - & - & - & 21.81 & 7.50 & - \\
\hline
\end{tabular}

The individual layers of Fe-hydroxides and Fe-oxides indicate intermediate iron content (50 to $65 \%$ ), with a mean of $56.6 \%$ (Figure 7). The manganese substitution is low and below $0.2 \%$, with a mean of $0.3 \%$. Only a few goethite data points show Mn incorporation elevated to 0.8 to $1.0 \%$. All samples show increased phosphorus contents (1.8 to $2.2 \%$ ), with a mean of $2.0 \%$. Additionally, the chemical analysis indicates the dominance of Si over Al. The mean silica content is $2.7 \%$, with few internal layers of goethite and hematite showing values elevated $>3.5 \%$. The $\mathrm{Al}$ content is low and rather evenly distributed in all samples; the mean is $0.4 \%$ and maximum values up to $0.8 \%$. The SEM-EDX data points show Ca dominance over $\mathrm{Mg}$. The mean Ca content is $1.8 \%$, with a maximum of $4.2 \%$. The distribution shows two modes, $1.0 \%$ and $2.2 \%$, respectively. Only two data points indicated Ca values above $3.6 \%$. The mean $\mathrm{Mg}$ content is low and equals to $0.18 \%$. The mean structural water $\mathrm{H}_{2} \mathrm{O}^{-}$amount calculated from the stoichiometry is $13.9 \%$. Samples show trace contents of $\mathrm{Na}$ and $\mathrm{K}$, $0.17 \%$ and $<0.10 \%$, respectively. The total alkalinity, calculated as a $(\mathrm{CaO}+\mathrm{MgO}) / \mathrm{SiO}_{2}$, is 0.17 .

The mean $\mathrm{Fe} / \mathrm{Mn}$ ratio equals 385 and $\mathrm{P} / \mathrm{Fe}$ is 0.04 . The mean $\mathrm{Ca} / \mathrm{P}$ ratio is 0.89 and $\mathrm{Ca} / \mathrm{Mg}$ equals 11.42. The $\mathrm{Si} / \mathrm{Al}$ ratio is 43.36 . The $\mathrm{Fe} / \mathrm{S}$ ratio calculated basing on 12 measurements is 167.17.

The pisolith nodules from the Roztoka Odrzańska indicate similar geochemical signatures to bog ores. According to the $\mathrm{SiO}_{2} / \mathrm{P}_{2} \mathrm{O}_{5}$ ratio, the EDX data samples are closer to pure Fe-oxides and Fe-hydroxides, compared to typical hematite rich ochres, siderite nodules or highly phosphatized Fe-rich precipitates (Figure 8). Compared to phosphate-rich nodules and bog ores, samples from the Roztoka Odrzańska indicate low phosphorus contents and only slight siderization. These results are in good correspondence with XRD data. 


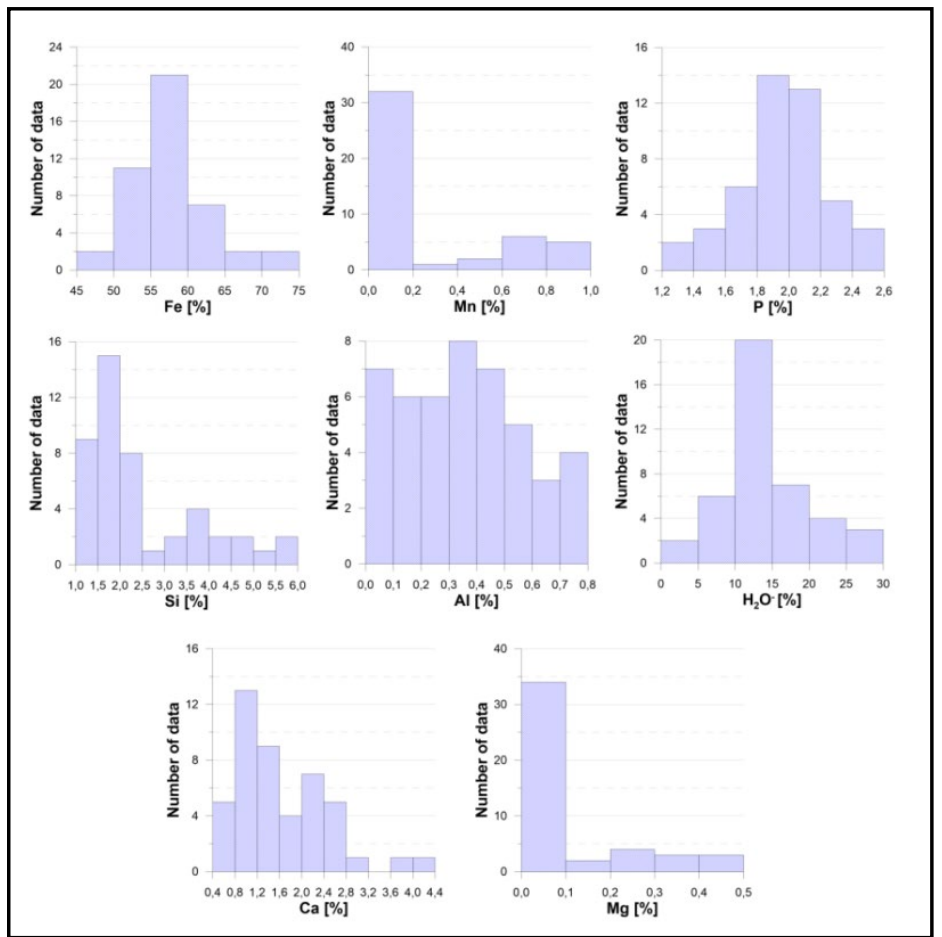

Figure 7. The SEM-EDX chemical variability of ferruginous micronodules from the Roztoka Odrzańska, Odra river, NW Poland. Structural water $\mathrm{H}_{2} \mathrm{O}^{-}$content calculated from the stoichiometry.

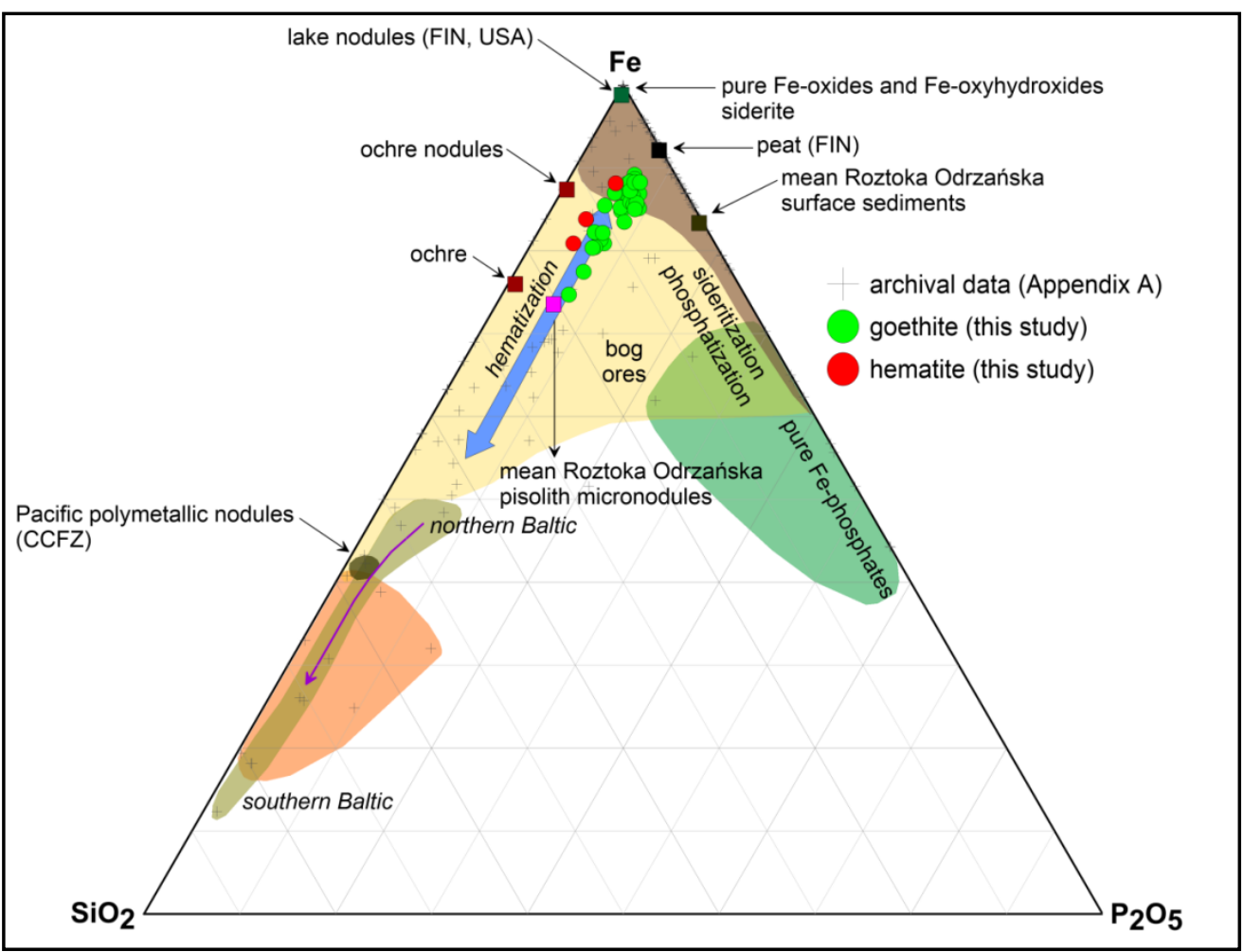

Figure 8. Discriminative ternary diagram compiled with data of the Roztoka Odrzańska nodules and archival geochemical results of different kinds of Fe-rich precipitates, selected rocks, sediments, and minerals. For the detailed description see Appendix A. 


\section{Discussion and Conclusions}

The morphological, chemical, and mineralogical variability of pisolith nodules from the Roztoka Odrzańska is closely related to the environmental conditions, characterized by high trophic level, presence of nutrient-rich peat bogs, good oxygenation and presence of glacial debris material (sands and silts). The Fe-dominated pisolith nodules were found in the small and shallow bay, among organic-rich sapropel muds, where the increased inflow of river water occurs and intensive drainage of the adjacent area is observed (Figure 9). The $\mathrm{pH}$ level of the Odra River, Szczecin Lagoon, and other small rivers are usually higher (7.2-8.4) compared to peats and organic sediments located within the area (usually $<6$ ), which provides good conditions to precipitation of iron compounds.

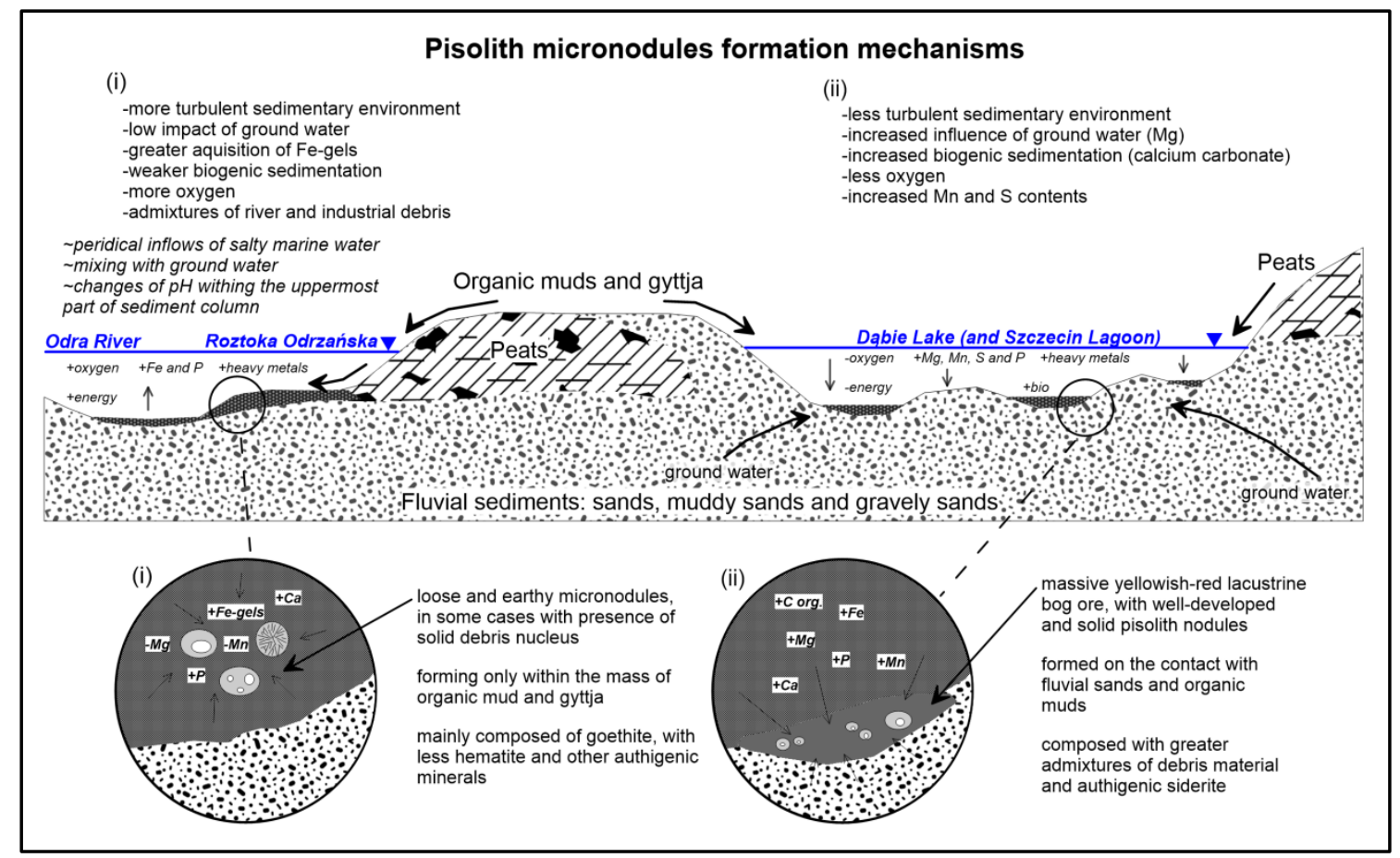

Figure 9. Discriminative ternary diagram compiled with data of the Roztoka Odrzańska nodules and archival geochemical results of different kinds of Fe-rich precipitates, selected rocks, sediments, and minerals. For the detailed description see Appendix A.

Described nodules were formed as a result of the precipitation of Fe-rich hydroxides, dominated by goethite, directly into the sediments. The iron source may be connected with nearby located peat bogs, soil processes or Fe-gels transported by the Gowienica river. Goethite usually forms in moist and highly oxidizing conditions. The presence of ferrihydrite, proto-hematite, and hematite is connected with further oxidation that might have taken place especially after the removal of the samples from the water, and the formation of the thin external cortex. These changes are also highlighted by cracking of the external layer, mainly due to some loss of structural water. Small admixtures of siderite suggest formation in freshwater, poor with sulphur, however rich in other organics [64]. Siderite forms when goethite (or lepidocrocite) is reduced by the decomposition of organic matter. Phosphorus incorporated within vivianite or metavivianite supposedly comes as a nutrient-rich drainage product, rather than weathering material $[65,66]$.

The elevated contents of $\mathrm{Al}, \mathrm{Ca}, \mathrm{Mg}$, Fe, and $\mathrm{Mn}$ in peat and sediments of the Roztoka Odrzańska are typical indicators of the organic-rich sedimentary environment. Additionally, the high $\mathrm{P}$ and $\mathrm{S}$ concentrations are natural and typically associated with organic sediments, however, some input from the Police fertilizer industry is also significant, being transported directly by the Odra river few 
kilometers north to the Roztoka Odrzańska, mixing with small drainage rivers cutting peats and gyttja sediments. The area of Roztoka Odrzańska is composed mainly of slightly acid soils ( $\mathrm{pH}>6$ ).

The composition of surface and groundwater indicate a typical inflow of freshwater sources. The marine input is visible rather in the northern part of the Szczecin Lagoon, however occasional marine water inflows were noted even in the deeper part of the Odra River system. Mixing of salty and groundwater affect cyclic, short-scale environmental changes of selected physicochemical parameters, especially $\mathrm{pH}$ and oxygenation, which potentially may induce Fe-precipitation, nucleation, and growth of pisolith nodules.

Some spots of more acidic soils and water may be connected with spots of anthropogenic materials. The greater ratios of $\mathrm{Fe} / \mathrm{S}$ and $\mathrm{P} / \mathrm{Fe}$ in the Roztoka Odrzańska pisolith nodules, compared to micronodules from the Dabie Lake and Szczecin Lagoon, suggest greater phosphorus release potential and lower impact on the formation of nodules [67]. The fractionation of $\mathrm{P} / \mathrm{Fe}$ ratios in surface sediments are strongly related to winter-summer cyclicality and changes of oxygen conditions [68]. The Police chemical industry phosphorus impact on the formation of nodule shall be part of further environmental studies.

The greater amount of detrital material inside micronodules (quartz, feldspar, zircon) and clays additionally confirm the precipitation of Fe-rich hydroxides in an oxygenated environment of increased water discharge. The increased content of phosphorus and presence of fresh blueish vivianite (or metavivianite) found inside pisoliths suggest diagenetic transformations due to the oxygen depletion. Increased contents of $\mathrm{Si}$, compared to $\mathrm{Al}$, and expressed by $\mathrm{Si} / \mathrm{Al}$ ratio $\sim 44$, suggests automorphic formation. The elevated amount of silica may not be connected only with the detrital quartz, but also with the colloidal organic matter (i.e., diatoms) dispersed in draining water [44].

Elevated concentrations of $\mathrm{Zn}$ and other heavy metals are associated mainly with the pollution transported by the Odra River from Police and southern Poland. However, the high contents of heavy metals are also associated with organic sediments of the Roztoka Odrzańska and peats of the neighboring areas, which are normally accumulated by natural processes [69]. One of the most problematic questions is, whether the presence of Zn-rich sulfo(carbonates) is a result of chemical weathering of anthropogenic slags or industrial dust included as internal debris in analyzed nodules, or whether these are natural decomposing minerals.

Compared to the Roztoka Odrzańska, the reference nodules from the Dabie Lake are dominated by primary siderite and $\mathrm{Mn}$-substituted siderite, potentially even with a small amount of rhodochrosite. The presence of $\mathrm{Mn}$-carbonate or greater $\mathrm{Mn}-(\mathrm{Mg})$ substitution in the chemistry of siderite and calcite is related to diagenesis in brackish conditions and the authigenic formation of components of fresh-lake sediments [70]. Admixtures of $\mathrm{FeO}$ (wüstite) may indicate the low influence of reductive processes. The low amount suggests formation in a more stable, well-oxygenated, and freshwater environment, compared to the Roztoka Odrzańska [71]. The greater amount of siderite in the Dabie Lake micronodules may be connected with worse trophic conditions, where $\mathrm{CO}_{2}$ is produced more intensively, due to increased decomposition of organic matter.

The loose and earthy spherical micronodules from the Roztoka Odrzańska were supposedly formed due to subaqueous authigenesis, dominated be Fe-oxyhydroxides, low amount of hematite, clay minerals, and presence of highly porous textures (compare i.e., [72]).

Morphological features of analyzed nodules suggest a rather fast growth (nucleation) rate, which shall be confirmed by additional isotopic studies and age estimation.

Studies of textures, mineralogy, and geochemistry of less known lacustrine pisolith nodules provide valuable information on sedimentary environmental conditions and regolith studies. Changes of metal and biogenic elements concentrations affect the early diagenetic formation of different types of micronodules. Highly organic Quaternary limnic or fluvial sediments are especially susceptible to authigenic growth, additionally supplied by admixtures of debris material. In some cases, the core of solid lacustrine micronodules may be composed even of material indicating anthropogenic signatures, often showing traces of intensive chemical decomposition. 
Author Contributions: Conceptualization, U.R., Ł.M., and A.S.; methodology, U.R., Ł.M., A.S., and S.S.; software, U.R., Ł.M., and S.S.; validation, Ł.M. and A.S.; formal analysis, A.S. and Ł.M.; investigation, U.R. and S.S.; resources, A.S., S.S., and Ł.M.; data curation, U.R., Ł.M., and S.S.; writing-original draft preparation, Ł.M. and U.R.; writing-review and editing, Ł.M., U.R., and A.S.; visualization, Ł.M. and U.R.; supervision, A.S.; funding acquisition, Ł.M., A.S., and S.S. All authors have read and agreed to the published version of the manuscript.

Funding: This research was financed by the Institute of Marine and Environmental Sciences, University of Szczecin, Poland statutory funds and sources of Polish Geological Institute-National Research Institute, Holy Cross Mts. Branch in Kielce, Poland.

Acknowledgments: We would like to thank Kamila Mianowicz, PhD (University of Szczecin), for linguistic assistance. We are grateful to prof. Ryszard K. Borówka and Dominik Zawadzki, PhD (University of Szczecin), for providing reference nodule samples from the Dąbie Lake and Szczecin Lagoon. Additionally, we would like to thank prof. Rafał J. Wróbel (West Pomeranian University of Technology) for XRD and XRF analysis. Finally, we would like to thank two reviewers for their positive feedback and valuable comments.

Conflicts of Interest: The authors declare no conflict of interest. The funders had no role in the design of the study; in the collection, analyses, or interpretation of data; in the writing of the manuscript, or in the decision to publish the results. 


\section{Appendix A}

Table A1. Archival data of the lake, lacustrine and riverine nodules, bog ores and other Fe-rich precipitates (see Figure 5).

\begin{tabular}{|c|c|c|c|c|c|c|c|c|c|c|c|c|c|}
\hline Location and Type & $\mathrm{SiO}_{2}$ & $\mathrm{P}_{2} \mathrm{O}_{5}$ & Fe & Mn & $\mathrm{Ca}$ & $\mathrm{Mg}$ & $\mathbf{S}$ & $\mathrm{Fe} / \mathrm{Mn}$ & $\mathrm{Ca} / \mathrm{Mg}$ & $\mathrm{P} / \mathrm{Fe}$ & $\mathrm{Fe} / \mathrm{S}$ & $\begin{array}{c}(\mathrm{CaO}+\mathrm{MgO}) / \\
\mathrm{SiO}_{2}\end{array}$ & $\begin{array}{c}\text { Data Source } \\
\text { (See References) }\end{array}$ \\
\hline & \multicolumn{7}{|c|}{$(\%)$} & - & - & - & - & - & \\
\hline Satterhutte, Krzyż, POL (bog ore) & 3.90 & 0.98 & 41.90 & 1.90 & & & & 22.05 & & 0.010 & & & [3] \\
\hline $\begin{array}{l}\text { Wisła, Wisłok and San river valleys, POL } \\
\text { (bog ore) }\end{array}$ & 19.35 & 2.14 & 28.69 & 2.89 & & & & 9.93 & & 0.033 & & & [3] \\
\hline $\begin{array}{l}\text { Biłgoraj-Tomaszów Mazowiecki, POL } \\
\text { (bog ore) }\end{array}$ & 21.00 & 1.12 & 29.32 & 3.00 & & & & 9.77 & & 0.017 & & & [3] \\
\hline Kalisz-Konin-Turek, POL (bog ore) & & 5.89 & 42.39 & 1.62 & & & & 26.17 & & 0.061 & & & [3] \\
\hline Mława-Łomża, POL (bog ore) & 11.83 & 3.64 & 34.38 & 0.75 & & & & 45.84 & & 0.046 & & & [3] \\
\hline Upper Silesia, POL (bog ore) & 28.10 & 0.25 & 36.04 & 1.20 & & & & 30.03 & & 0.003 & & & [3] \\
\hline Wieluń, POL (bog ore) & 18.55 & 2.80 & 41.69 & 0.86 & & & & 48.48 & & 0.029 & & & [3] \\
\hline Mazowieckie Voivodeship, POL (bog ore) & & 0.04 & 29.53 & 2.43 & & & & 12.15 & & 0.001 & & & [3] \\
\hline Łódzkie Voivodeship, POL (bog ore) & & 8.06 & 31.14 & 2.79 & & & & 11.16 & & 0.113 & & & [3] \\
\hline Glinne, POL (bog ore) & 30.11 & & 30.11 & 2.11 & 1.03 & & 0.14 & 14.27 & & & 209.1 & 0.048 & [3] \\
\hline $\begin{array}{l}\text { Bobrowniki I, POL (rusty-yellowish } \\
\text { bog ore) }\end{array}$ & 6.84 & & 35.55 & 0.27 & 2.02 & 0.13 & 0.19 & 131.67 & 15.91 & & 185.2 & 0.444 & [3] \\
\hline Bobrowniki II, POL (red bog ore) & 3.16 & & 46.62 & 0.26 & 1.13 & 0.12 & 0.17 & 179.31 & 9.83 & & 277.5 & 0.561 & [3] \\
\hline Rubinkowo I, POL (bog ore) & 6.60 & & 45.79 & 2.01 & 1.59 & 0.41 & 0.07 & 22.78 & 3.88 & & 636.0 & 0.440 & [3] \\
\hline Rubinkowo II, POL (bog ore) & 9.40 & & 40.64 & 2.64 & 2.23 & 0.37 & 0.06 & 15.39 & 5.96 & & 635.0 & 0.398 & [3] \\
\hline Białystok, POL (bog ore) & 14.90 & & 29.83 & & & & & & & & & & [3] \\
\hline Lublin, POL (bog ore) & 19.39 & & 26.68 & & & & & & & & & & [3] \\
\hline Olsztyn, POL (bog ore) & 12.66 & & 28.09 & & & & & & & & & & [3] \\
\hline Poznań, POL (bog ore) & 23.38 & & 40.23 & & & & & & & & & & [3] \\
\hline Rzeszów, POL (bog ore) & 21.14 & & 29.12 & & & & & & & & & & [3] \\
\hline Mazowieckie Voivodeship, POL (bog ore) & 34.49 & 0.84 & 26.97 & 2.01 & 0.50 & 0.05 & 0.08 & 13.42 & 10.00 & 0.014 & 336.3 & 0.023 & [3] \\
\hline Biedaszki, POL (bog ore) & 3.03 & 5.19 & 49.60 & 2.67 & 1.69 & 0.15 & & 18.58 & 11.27 & 0.046 & & 0.863 & [3] \\
\hline Dąbrówka, POL (bog ore) & 14.57 & 3.65 & 39.36 & 0.15 & 0.52 & 0.13 & & 262.40 & 4.09 & 0.040 & & 0.064 & [3] \\
\hline Dębe Małe (bog ore) & 15.00 & 5.59 & 27.37 & 0.41 & 2.08 & 0.12 & & 66.76 & 17.19 & 0.089 & & 0.208 & [3] \\
\hline Grądy Dolne (bog ore) & 22.81 & 2.87 & 30.56 & 9.64 & 1.23 & 0.16 & & 3.17 & 7.55 & 0.041 & & 0.087 & [3] \\
\hline Kuźnica Słupska, POL (bog ore) & 7.04 & 10.03 & 27.74 & 0.78 & 2.60 & 0.33 & & 35.56 & 7.98 & 0.158 & & 0.594 & [3] \\
\hline Strzyżew, POL (bog ore) & 1.53 & 2.03 & 36.40 & 0.25 & 0.97 & 0.06 & & 145.60 & 16.09 & 0.024 & & 0.953 & [3] \\
\hline Mean soft bog ores, POL & 11.08 & 4.54 & 32.71 & 0.31 & 1.31 & 0.21 & & 105.52 & 6.21 & 0.061 & & 0.197 & [3] \\
\hline Mean solid bog ores, POL & 36.89 & 3.52 & 25.63 & 2.48 & 1.05 & 0.18 & & 10.33 & 6.00 & 0.060 & & 0.048 & [3] \\
\hline $\begin{array}{l}\text { Roztoka Odrzańska, POL } \\
\quad \text { (pisolith nodules) }\end{array}$ & 14.04 & 4.11 & 50.42 & 0.28 & 1.52 & 0.16 & 0.72 & 385.45 & 9.50 & 0.036 & 167.2 & 0.170 & This study \\
\hline
\end{tabular}


Table A1. Cont.

\begin{tabular}{|c|c|c|c|c|c|c|c|c|c|c|c|c|c|}
\hline Location and Type & $\mathrm{SiO}_{2}$ & $\mathbf{P}_{2} \mathrm{O}_{5}$ & Fe & Mn & $\mathrm{Ca}$ & $\mathrm{Mg}$ & $S$ & $\mathrm{Fe} / \mathrm{Mn}$ & $\mathrm{Ca} / \mathrm{Mg}$ & $\mathrm{P} / \mathrm{Fe}$ & $\mathrm{Fe} / \mathrm{S}$ & $\begin{array}{c}(\mathrm{CaO}+\mathrm{MgO}) / \\
\mathrm{SiO}_{2}\end{array}$ & $\begin{array}{c}\text { Data Source } \\
\text { (See References) }\end{array}$ \\
\hline & \multicolumn{7}{|c|}{$(\%)$} & - & - & - & - & - & \\
\hline $\begin{array}{l}\text { Ruukki-Vihanti, FIN (Fe-rich mire } \\
\text { precipitates: black amorphic and vivianite) }\end{array}$ & 4.20 & 2.00 & 43.82 & 0.02 & 0.21 & 0.02 & 0.02 & 2921.33 & 11.86 & 0.020 & 2191.0 & 0.079 & {$[64]$} \\
\hline $\begin{array}{l}\text { Ruukki-Vihanti, FIN (Fe-rich mire } \\
\text { precipitates: vivanite and sand) }\end{array}$ & 35.80 & 9.20 & 21.21 & 0.05 & 0.50 & 0.78 & 0.01 & 461.09 & 0.64 & 0.189 & 2121.0 & 0.056 & {$[64]$} \\
\hline $\begin{array}{l}\text { Ruukki-Vihanti, FIN (Fe-rich mire } \\
\text { precipitates: yellow, black streaked, } \\
\text { siderite and vivianite) }\end{array}$ & 1.00 & 2.10 & 58.97 & 0.09 & 0.29 & 0.01 & 0.01 & 634.09 & 47.43 & 0.016 & 5897.0 & 0.410 & [64] \\
\hline $\begin{array}{l}\text { Ruukki-Vihanti, FIN (Fe-rich mire } \\
\text { precipitates: pale yellow, fine } \\
\text { grained, siderite) }\end{array}$ & 2.30 & 0.50 & 61.23 & 0.23 & 0.36 & 0.01 & 0.01 & 263.92 & 29.64 & 0.004 & 6123.0 & 0.226 & [64] \\
\hline $\begin{array}{l}\text { Ruukki-Vihanti, FIN (Fe-rich mire } \\
\text { precipitates: green, coarse } \\
\text { grained, siderite) }\end{array}$ & 4.60 & 0.30 & 60.06 & 0.14 & 0.21 & 0.02 & 0.01 & 432.09 & 11.86 & 0.002 & 6006.0 & 0.072 & [64] \\
\hline $\begin{array}{l}\text { Ruukki-Vihanti, FIN (Fe-rich mire } \\
\text { precipitates: pale yellow, bedded, siderite) }\end{array}$ & 0.40 & 0.10 & 61.85 & 0.26 & 0.43 & 0.02 & 0.01 & 235.17 & 17.79 & 0.001 & 6185.0 & 1.602 & {$[64]$} \\
\hline $\begin{array}{l}\text { Ruukki-Vihanti, FIN (Fe-rich mire } \\
\text { precipitates: brown oxidized surface, } \\
\text { goethite and limonite) }\end{array}$ & 0.50 & 0.10 & 66.36 & 0.08 & 0.14 & 0.01 & 0.01 & 857.36 & 23.71 & 0.001 & 6636.0 & 0.420 & [64] \\
\hline $\begin{array}{l}\text { Ruukki-Vihanti, FIN (Fe-rich mire } \\
\text { precipitates: brown oxidized, fine grained } \\
\text { with dark nodules, goethite and limonite) }\end{array}$ & 2.40 & 1.30 & 62.39 & 0.01 & 0.07 & 0.01 & 0.01 & 8060.72 & 5.93 & 0.009 & 6239.0 & 0.050 & [64] \\
\hline $\begin{array}{c}\text { Ruukki-Vihanti (42), FIN (Fe-rich mire } \\
\text { precipitates: black amorphic, siderite } \\
\text { and vivianite) }\end{array}$ & & 10.65 & 25.20 & 0.09 & 0.12 & 0.25 & 0.59 & 280.00 & 0.48 & 0.184 & 42.7 & & [64] \\
\hline $\begin{array}{l}\text { Ruukki-Vihanti (43), FIN (Fe-rich mire } \\
\text { precipitates: black amorphic) }\end{array}$ & & 4.63 & 16.90 & 0.07 & 0.27 & 0.31 & 1.37 & 241.43 & 0.87 & 0.119 & 12.3 & & [64] \\
\hline $\begin{array}{l}\text { Ruukki-Vihanti (48), FIN (Fe-rich mire } \\
\text { precipitates: black amorphic, siderite } \\
\text { and vivianite) }\end{array}$ & & 6.05 & 31.50 & 0.10 & 0.24 & 0.36 & 0.10 & 315.00 & 0.67 & 0.084 & 315.0 & & [64] \\
\hline $\begin{array}{l}\text { Ruukki-Vihanti (50), FIN (Fe-rich mire } \\
\text { precipitates: black amorphic, siderite } \\
\text { and vivianite) }\end{array}$ & & 14.24 & 26.50 & 0.14 & 0.31 & 0.69 & 0.57 & 189.29 & 0.45 & 0.234 & 46.5 & & [64] \\
\hline $\begin{array}{l}\text { Ruukki-Vihanti (54), FIN (Fe-rich mire } \\
\text { precipitates: black amorphic, siderite) }\end{array}$ & & 1.97 & 20.70 & 0.04 & 0.24 & 0.48 & 0.14 & 517.50 & 0.50 & 0.041 & 147.9 & & [64] \\
\hline $\begin{array}{l}\text { Ruukki-Vihanti (55), FIN (Fe-rich mire } \\
\text { precipitates: black amorphic) }\end{array}$ & & 4.88 & 17.00 & 0.07 & 0.36 & 0.65 & 0.33 & 242.86 & 0.55 & 0.125 & 51.5 & & [64] \\
\hline
\end{tabular}


Table A1. Cont.

\begin{tabular}{|c|c|c|c|c|c|c|c|c|c|c|c|c|c|}
\hline Location and Type & $\mathrm{SiO}_{2}$ & $\mathrm{P}_{2} \mathrm{O}_{5}$ & $\mathrm{Fe}$ & Mn & $\mathrm{Ca}$ & $\mathrm{Mg}$ & $\mathrm{S}$ & $\mathrm{Fe} / \mathrm{Mn}$ & $\mathrm{Ca} / \mathrm{Mg}$ & $\mathrm{P} / \mathrm{Fe}$ & $\mathrm{Fe} / \mathrm{S}$ & $\begin{array}{c}(\mathrm{CaO}+\mathrm{MgO}) / \\
\mathrm{SiO}_{2}\end{array}$ & $\begin{array}{c}\text { Data Source } \\
\text { (See References) }\end{array}$ \\
\hline & \multicolumn{7}{|c|}{$(\%)$} & - & - & - & - & - & \\
\hline $\begin{array}{l}\text { Ruukki-Vihanti (58), FIN (Fe-rich mire } \\
\text { precipitates: black amorphic, siderite) }\end{array}$ & & 3.94 & 15.20 & 0.05 & 0.38 & 0.68 & 0.25 & 304.00 & 0.56 & 0.113 & 60.8 & & [64] \\
\hline $\begin{array}{l}\text { Ruukki-Vihanti (60), FIN (Fe-rich mire } \\
\text { precipitates: black amorphic, siderite } \\
\text { and vivianite) }\end{array}$ & & 16.12 & 26.70 & 0.16 & 0.16 & 0.34 & 0.26 & 166.88 & 0.47 & 0.263 & 102.7 & & [64] \\
\hline $\begin{array}{l}\text { Ruukki-Vihanti (63), FIN (Fe-rich mire } \\
\text { precipitates: black amorphic, siderite } \\
\text { and vivianite) }\end{array}$ & & 6.73 & 12.10 & 0.09 & 0.25 & 0.51 & 2.17 & 134.44 & 0.49 & 0.243 & 5.6 & & [64] \\
\hline $\begin{array}{l}\text { Ruukki-Vihanti (65), FIN (Fe-rich mire } \\
\text { precipitates: siderite) }\end{array}$ & & 3.30 & 31.80 & 0.09 & 0.43 & 0.27 & 0.05 & 353.33 & 1.59 & 0.045 & 636.0 & & [64] \\
\hline $\begin{array}{l}\text { Ruukki-Vihanti (67), FIN (Fe-rich mire } \\
\text { precipitates: siderite) }\end{array}$ & & 2.08 & 29.10 & 0.08 & 0.29 & 0.31 & 0.06 & 363.75 & 0.94 & 0.031 & 485.0 & & [64] \\
\hline $\begin{array}{l}\text { Ruukki-Vihanti (68), FIN (Fe-rich mire } \\
\text { precipitates: siderite) }\end{array}$ & & 1.81 & 37.80 & 0.17 & 0.32 & 0.25 & 0.04 & 222.35 & 1.28 & 0.021 & 945.0 & & [64] \\
\hline $\begin{array}{l}\text { Ruukki-Vihanti (69), FIN (Fe-rich mire } \\
\text { precipitates: black amorphic) }\end{array}$ & & 1.81 & 20.90 & 0.04 & 0.27 & 0.47 & 0.24 & 522.50 & 0.57 & 0.038 & 87.1 & & [64] \\
\hline $\begin{array}{l}\text { Ruukki-Vihanti (74), FIN (Fe-rich mire } \\
\text { precipitates: black amorphic, siderite) }\end{array}$ & & 2.79 & 19.50 & 0.03 & 0.21 & 0.41 & 0.13 & 650.00 & 0.51 & 0.062 & 150.0 & & [64] \\
\hline $\begin{array}{l}\text { Ruukki-Vihanti (75), FIN (Fe-rich mire } \\
\text { precipitates: siderite) }\end{array}$ & & 1.56 & 37.20 & 0.11 & 0.28 & 0.29 & 0.03 & 338.18 & 0.97 & 0.018 & 1240.0 & & [64] \\
\hline $\begin{array}{l}\text { Ruukki-Vihanti (76), FIN (Fe-rich mire } \\
\text { precipitates: black amorphic, siderite } \\
\text { and vivianite) }\end{array}$ & & 7.37 & 25.90 & 0.14 & 0.21 & 0.42 & 0.12 & 185.00 & 0.50 & 0.124 & 215.8 & & [64] \\
\hline Peat Kirjaneva, FIN & & 0.32 & 4.00 & 0.02 & 0.34 & 0.55 & 0.63 & 210.53 & 0.62 & 0.035 & 6.3 & & [64] \\
\hline $\begin{array}{c}\text { Surface sediments from Roztoka } \\
\text { Odrzańska, POL }\end{array}$ & & 0.52 & 2.80 & 0.17 & 3.50 & 0.25 & 0.95 & 16.47 & 14.00 & 0.081 & 2.9 & & This study \\
\hline $\begin{array}{c}\text { Equatorial Pacific (CCFZ) polymetallic } \\
\text { nodules, IOM }\end{array}$ & 16.48 & 0.57 & 12.50 & 18.60 & 2.30 & 1.60 & 0.50 & 0.67 & 1.44 & 0.020 & 25.0 & 0.357 & [73] \\
\hline Baltic Sea, Słupsk Bank, POL (nodules) & 36.76 & 1.68 & 13.55 & 9.75 & 0.81 & 1.23 & 0.04 & 1.39 & 0.66 & 0.054 & 338.8 & 0.086 & [74] \\
\hline $\begin{array}{l}\text { Szklarka Przygodzicka, POL (solid } \\
\text { bog ore) }\end{array}$ & 25.90 & 4.17 & 30.61 & 3.55 & 0.50 & 0.05 & 0.02 & 8.62 & 9.26 & 0.059 & 1530.5 & 0.030 & [75] \\
\hline Studzieniec, POL (solid bog ore) & 18.32 & 3.56 & 38.36 & 1.42 & 0.85 & 0.07 & 0.08 & 27.01 & 12.88 & 0.040 & 479.5 & 0.071 & [75] \\
\hline Wilanów, POL (solid bog ore) & 17.83 & 5.13 & 43.33 & 0.60 & & & & 72.22 & & 0.052 & & & [13] \\
\hline
\end{tabular}


Table A1. Cont.

\begin{tabular}{|c|c|c|c|c|c|c|c|c|c|c|c|c|c|}
\hline Location and Type & $\mathrm{SiO}_{2}$ & $\mathrm{P}_{2} \mathrm{O}_{5}$ & $\mathrm{Fe}$ & Mn & $\mathrm{Ca}$ & $\mathrm{Mg}$ & S & $\mathrm{Fe} / \mathrm{Mn}$ & $\mathrm{Ca} / \mathrm{Mg}$ & $\mathrm{P} / \mathrm{Fe}$ & $\mathrm{Fe} / \mathrm{S}$ & $\begin{array}{l}(\mathrm{CaO}+\mathrm{MgO}) / \\
\mathrm{SiO}_{2}\end{array}$ & $\begin{array}{c}\text { Data Source } \\
\text { (See References) }\end{array}$ \\
\hline & \multicolumn{7}{|c|}{$(\%)$} & - & - & - & - & - & \\
\hline $\begin{array}{c}\text { Northern Praga, Warszawa, POL (solid } \\
\text { bog ore) }\end{array}$ & 16.41 & 5.36 & 49.20 & 0.36 & & & & 136.67 & & 0.047 & & & [13] \\
\hline Brwinów, POL (soft bog ore) & 4.49 & 7.53 & 45.35 & 0.87 & & & & 52.13 & & 0.072 & & & [13] \\
\hline Tisjoen Lake, NOR (Fe-rich lake nodules) & & & 50.05 & 1.83 & & & & 27.35 & & & & & [25] \\
\hline Dębe Małe II, POL (soft bog ore) & 4.02 & 7.68 & 44.16 & 1.28 & 2.05 & 1.52 & & 34.50 & 1.35 & 0.076 & & 1.342 & [16] \\
\hline Kolechowice, POL (soft bog ore) & 7.88 & 3.11 & 33.52 & 0.17 & 1.88 & 0.05 & & 197.18 & 39.17 & 0.040 & & 0.344 & [16] \\
\hline $\begin{array}{l}\text { Lowland Point (cliff), Lizard, ENG (solid } \\
\text { bog ore formed on magmatic rocks) }\end{array}$ & 34.49 & 0.47 & 24.05 & 2.85 & 0.52 & 0.78 & 0.07 & 8.44 & 0.67 & 0.009 & 343.6 & 0.059 & [76] \\
\hline Nowosielec, POL (Quaternary bog ore) & & & 42.07 & & & & & & & & & & [77] \\
\hline $\begin{array}{c}\text { Wola Chorzelowska, POL (Quaternary } \\
\text { bog ore) }\end{array}$ & & 2.38 & 26.04 & 2.04 & & & & 12.76 & & 0.040 & & & [77] \\
\hline Cmolas, POL (Quaternary bog ore) & & 2.41 & 39.50 & 1.31 & & & & 30.15 & & 0.027 & & & [77] \\
\hline Ruda, POL (Quaternary bog ore) & & 4.31 & 31.90 & 4.52 & & & & 7.06 & & 0.059 & & & [77] \\
\hline Biały Bór, POL (Quaternary bog ore) & & 1.60 & 33.15 & 3.18 & & & & 10.42 & & 0.021 & & & [77] \\
\hline Lipa, POL (Quaternary bog ore) & & 1.60 & 29.32 & & & & & & & 0.024 & & & [77] \\
\hline Krownice, POL (Quaternary bog ore) & & 1.74 & 27.72 & 2.62 & & & & 10.58 & & 0.027 & & & [77] \\
\hline Ocieka-Zdziary, POL (Quaternary bog ore) & & 1.52 & 33.95 & 4.94 & & & & 6.87 & & 0.020 & & & [77] \\
\hline Prażuchy, POL (Quaternary bog ore) & & & 30.04 & & & & & & & & & & [77] \\
\hline $\begin{array}{c}\text { Kuźnica-Zakrzyn, POL (Quaternary } \\
\text { bog ore) }\end{array}$ & & 7.61 & 40.64 & 0.81 & & & & 50.17 & & 0.082 & & & [77] \\
\hline Annopol, POL (Quaternary bog ore) & & 4.74 & 29.53 & 2.88 & & & & 10.25 & & 0.070 & & & [77] \\
\hline Jarantów, POL (Quaternary bog ore) & & 5.48 & 36.51 & 0.35 & & & & 104.31 & & 0.065 & & & [77] \\
\hline $\begin{array}{c}\text { Stojanów-Modła, POL (Quaternary } \\
\text { bog ore) }\end{array}$ & & 2.37 & 24.39 & 2.22 & & & & 10.99 & & 0.042 & & & [77] \\
\hline Sobiesęki, POL (Quaternary bog ore) & & 6.75 & 35.37 & 2.04 & & & & 17.34 & & 0.083 & & & [77] \\
\hline Zajęczki, POL (Quaternary bog ore) & & 6.73 & 40.70 & 1.41 & & & & 28.87 & & 0.072 & & & [77] \\
\hline $\begin{array}{l}\text { Łęki Godzieskie, POL (Quaternary } \\
\text { bog ore) }\end{array}$ & & 4.25 & 24.50 & 4.87 & & & & 5.03 & & 0.076 & & & [77] \\
\hline Grodziec, POL (Quaternary bog ore) & & 1.86 & 42.06 & 0.86 & & & & 48.91 & & 0.019 & & & [77] \\
\hline $\begin{array}{c}\text { Kolonia Łazińska, POL (Quaternary } \\
\text { bog ore) }\end{array}$ & & 5.09 & 34.26 & 3.87 & & & & 8.85 & & 0.065 & & & [77] \\
\hline Gozdów, POL (Quaternary bog ore) & & 5.58 & 44.03 & 1.40 & & & & 31.45 & & 0.055 & & & [77] \\
\hline Skrzynno, POL (Quaternary bog ore) & & 8.80 & 41.28 & 1.00 & & & & 41.28 & & 0.093 & & & [77] \\
\hline $\begin{array}{c}\text { Krzynowłoga Mała, POL (Quaternary } \\
\text { bog ore) }\end{array}$ & & 2.12 & 17.57 & & & & & & & 0.053 & & & [77] \\
\hline
\end{tabular}


Table A1. Cont.

\begin{tabular}{|c|c|c|c|c|c|c|c|c|c|c|c|c|c|}
\hline Location and Type & $\mathrm{SiO}_{2}$ & $\mathbf{P}_{2} \mathrm{O}_{5}$ & Fe & Mn & $\mathrm{Ca}$ & $\mathrm{Mg}$ & $\mathrm{S}$ & $\mathrm{Fe} / \mathrm{Mn}$ & $\mathrm{Ca} / \mathrm{Mg}$ & $\mathrm{P} / \mathrm{Fe}$ & $\mathrm{Fe} / \mathrm{S}$ & $\begin{array}{l}(\mathrm{CaO}+\mathrm{MgO}) / \\
\mathrm{SiO}_{2}\end{array}$ & $\begin{array}{c}\text { Data Source } \\
\text { (See References) }\end{array}$ \\
\hline & \multicolumn{7}{|c|}{$(\%)$} & - & - & - & - & - & \\
\hline Małowidz, POL (Quaternary bog ore) & & 6.63 & 33.85 & & & & & & & 0.085 & & & [77] \\
\hline Kadzidło, POL (Quaternary bog ore) & & 2.80 & 33.44 & & & & & & & 0.037 & & & [77] \\
\hline Krobia, POL (Quaternary bog ore) & & 5.29 & 34.90 & & & & & & & 0.066 & & & [77] \\
\hline Wydmusy, POL (Quaternary bog ore) & & 3.71 & 27.40 & & & & & & & 0.059 & & & [77] \\
\hline Oberwia, POL (Quaternary bog ore) & & 4.35 & 49.84 & 0.50 & & & & 99.68 & & 0.038 & & & [77] \\
\hline Przystań, POL (Quaternary bog ore) & & 4.38 & 26.02 & & & & & & & 0.073 & & & [77] \\
\hline Łazy, POL (Quaternary bog ore) & & 3.75 & 24.93 & & & & & & & 0.066 & & & [77] \\
\hline Ruda, POL (Quaternary bog ore) & & 2.28 & 32.18 & & & & & & & 0.031 & & & [77] \\
\hline Krasny Borek, POL (Quaternary bog ore) & & 3.97 & 31.79 & & & & & & & 0.054 & & & [77] \\
\hline Krebki, POL (Quaternary bog ore) & & 3.29 & 27.33 & & & & & & & 0.052 & & & [77] \\
\hline Nowa Ruda, POL (Quaternary bog ore) & & 5.75 & 33.27 & & & & & & & 0.075 & & & [77] \\
\hline Zabiele, POL (Quaternary bog ore) & & 4.08 & 47.82 & 0.39 & & & & 122.62 & & 0.037 & & & [77] \\
\hline $\begin{array}{l}\text { Błonie-Miedniewice, POL (Quaternary } \\
\text { bog ore) }\end{array}$ & & 3.52 & 34.80 & 2.43 & & & & 14.32 & & 0.044 & & & [77] \\
\hline $\begin{array}{c}\text { Garwolin kol. Czarnica, POL (Quaternary } \\
\text { bog ore) }\end{array}$ & & 2.31 & 37.97 & & & & & & & 0.027 & & & [77] \\
\hline Bramka, POL (Quaternary bog ore) & & 2.50 & 33.68 & & & & & & & 0.032 & & & [77] \\
\hline $\begin{array}{c}\text { Torun Bobrowniki, POL (Quaternary } \\
\text { bog ore) }\end{array}$ & & 3.95 & 41.11 & 0.22 & & & & 186.86 & & 0.042 & & & [77] \\
\hline $\begin{array}{c}\text { Szczytno Męcice, POL (Quaternary } \\
\text { bog ore) }\end{array}$ & & 4.12 & 37.00 & 1.22 & & & & 30.33 & & 0.049 & & & [77] \\
\hline Lesiny Wielkie, POL (Quaternary bog ore) & & 2.64 & 44.00 & & & & & & & 0.026 & & & [77] \\
\hline Łuka, POL (Quaternary bog ore) & & 0.64 & 35.50 & & & & & & & 0.008 & & & [77] \\
\hline Kołodziej Grad, POL (Quaternary bog ore) & & & 28.75 & & & & & & & & & & [77] \\
\hline $\begin{array}{c}\text { Myszyniec Wykrot, POL (Quaternary } \\
\text { bog ore) }\end{array}$ & & 2.65 & 35.96 & 0.84 & & & & 42.81 & & 0.032 & & & [77] \\
\hline Riga Bay, Baltic Sea, LT (nodules) & 24.07 & 1.65 & 22.65 & 10.36 & 1.54 & 0.33 & & 2.19 & 4.67 & 0.032 & & 0.112 & [78] \\
\hline Finland Bay, Baltic Sea, FIN (nodules) & 17.42 & 2.76 & 18.96 & 15.78 & 1.66 & 0.60 & & 1.20 & 2.77 & 0.063 & & 0.191 & [78] \\
\hline Central Baltic, POL (nodules) & 35.33 & 2.09 & 16.62 & 10.80 & 1.15 & 0.72 & & 1.54 & 1.60 & 0.055 & & 0.079 & [78] \\
\hline residual Jurassic (J2) Fe-rich sands, POL & 67.00 & 0.32 & 16.20 & 0.40 & 0.50 & 0.10 & 0.12 & 40.50 & 5.00 & 0.009 & 135.0 & 0.013 & [79] \\
\hline $\begin{array}{c}\text { Wierzbowa, Bolesławiec, POL (Quaternary } \\
\text { bog ore) }\end{array}$ & 28.20 & 4.58 & 35.20 & 2.50 & & & & 14.08 & & 0.057 & & & [79] \\
\hline $\begin{array}{l}\text { Grabowa, Ostrów Wielkopolski, POL } \\
\text { (Quaternary bog ore) }\end{array}$ & 7.20 & 8.48 & 48.60 & 3.40 & & & & 14.29 & & 0.076 & & & [79] \\
\hline $\begin{array}{c}\text { Zajączki, Ostrów Wielkopolski, POL } \\
\text { (Quaternary bog ore) }\end{array}$ & & 8.02 & 47.20 & 0.60 & & & & 78.67 & & 0.074 & & & [79] \\
\hline
\end{tabular}


Table A1. Cont.

\begin{tabular}{|c|c|c|c|c|c|c|c|c|c|c|c|c|c|}
\hline Location and Type & $\mathrm{SiO}_{2}$ & $\mathrm{P}_{2} \mathrm{O}_{5}$ & $\mathrm{Fe}$ & Mn & $\mathrm{Ca}$ & $\mathrm{Mg}$ & $S$ & $\mathrm{Fe} / \mathrm{Mn}$ & $\mathrm{Ca} / \mathrm{Mg}$ & $\mathrm{P} / \mathrm{Fe}$ & $\mathrm{Fe} / \mathrm{S}$ & $\begin{array}{l}(\mathrm{CaO}+\mathrm{MgO}) / \\
\mathrm{SiO}_{2}\end{array}$ & $\begin{array}{c}\text { Data Source } \\
\text { (See References) }\end{array}$ \\
\hline & \multicolumn{7}{|c|}{$(\%)$} & - & - & - & - & - & \\
\hline $\begin{array}{c}\text { Małowich, Przasnysz, POL (Quaternary } \\
\text { bog ore) }\end{array}$ & & 6.65 & 33.80 & 1.20 & & & & 28.17 & & 0.086 & & & [79] \\
\hline $\begin{array}{c}\text { Chorzele, Przasnysz, POL (Quaternary } \\
\text { bog ore) }\end{array}$ & 10.60 & 4.28 & 35.43 & 0.93 & & & & 38.10 & & 0.053 & & & [79] \\
\hline $\begin{array}{c}\text { Ziomek, Przasnysz, POL (Quaternary } \\
\text { bog ore) }\end{array}$ & 4.60 & & 45.50 & & & & & & & & & & [79] \\
\hline $\begin{array}{c}\text { Wólka Katna, Puławy, POL (Quaternary } \\
\text { bog ore) }\end{array}$ & 16.70 & & 28.80 & & & & & & & & & & [79] \\
\hline $\begin{array}{c}\text { Cmolas II, Wisła-San, POL (Quaternary } \\
\text { bog ore) }\end{array}$ & 10.50 & 3.67 & 42.00 & 1.30 & 0.79 & & 1.10 & 32.31 & & 0.038 & 38.2 & 0.105 & [79] \\
\hline $\begin{array}{c}\text { Rudawa, Wisła-San, POL (Quaternary } \\
\text { bog ore) }\end{array}$ & 33.80 & 1.15 & 33.60 & 1.00 & & & & 33.60 & & 0.015 & & & [79] \\
\hline $\begin{array}{c}\text { Trzciana, Wisła-San, POL (Quaternary } \\
\text { bog ore) }\end{array}$ & 20.00 & 1.37 & 33.00 & 0.90 & 1.36 & & 2.20 & 36.67 & & 0.018 & 15.0 & 0.095 & [79] \\
\hline $\begin{array}{c}\text { Bratkowice, Wisła-San, POL (Quaternary } \\
\text { bog ore) }\end{array}$ & 11.30 & 3.90 & 34.30 & 0.30 & & & & 114.33 & & 0.050 & & & [79] \\
\hline Jamno, Łódź, POL (Quaternary bog ore) & 9.40 & 7.10 & 38.50 & 1.00 & & & & 38.50 & & 0.080 & & & [79] \\
\hline Zawady, Łódź, POL (Quaternary bog ore) & 15.60 & 5.27 & 34.50 & 1.10 & & & & 31.36 & & 0.067 & & & [79] \\
\hline $\begin{array}{c}\text { Dylewo, Warszawa, POL (Quaternary } \\
\text { bog ore) }\end{array}$ & 4.10 & 10.54 & 30.00 & 0.30 & 1.57 & & & 100.00 & & 0.153 & & 0.536 & [79] \\
\hline Czerwonki Hermanowskie, POL (ochre) & 14.10 & 0.22 & 45.88 & 1.40 & 0.15 & 0.17 & & 32.77 & 0.88 & 0.002 & & 0.035 & [80] \\
\hline $\begin{array}{l}\text { Czerwonki Hermanowskie, POL } \\
\text { (clayey ochre) }\end{array}$ & 44.76 & 0.20 & 22.13 & 0.85 & 0.24 & 0.68 & & 26.04 & 0.35 & 0.004 & & 0.033 & [80] \\
\hline $\begin{array}{l}\text { Czerwonki Hermanowskie, POL } \\
\text { (Fe-nodules) }\end{array}$ & 6.74 & 0.12 & 47.38 & 5.97 & 0.03 & 0.01 & & 7.94 & 3.00 & 0.001 & & 0.009 & [80] \\
\hline Czerwonki Hermanowskie, POL (Fe-gel) & 37.25 & 5.39 & 14.10 & 0.59 & 1.92 & 0.19 & & 23.90 & 10.11 & 0.167 & & 0.081 & [80] \\
\hline Lorraine I, FRA (Jurassic limonite ore) & 8.20 & 1.37 & 31.10 & & 9.28 & 2.61 & 0.12 & 3.35 & 3.56 & 0.019 & 259.2 & 2.113 & [81] \\
\hline Lorraine II, FRA (Jurassic limonite ore) & 17.10 & 1.38 & 32.10 & & 5.42 & 1.53 & 0.28 & 5.92 & 3.54 & 0.019 & 114.6 & 0.592 & [81] \\
\hline Maghemite (pure mineral) & 0.30 & & 52.15 & 0.57 & & 5.07 & & & & & & 28.054 & [82] \\
\hline Hematite (pure mineral) & & & 69.60 & 0.67 & & & & & & & & & [82] \\
\hline Goethite (pure mineral) & 0.36 & & 62.67 & & & & & & & & & & [82] \\
\hline Lepidocrocite (pure mineral) & & & 62.84 & & & & & & & & & & [82] \\
\hline Feroxyhyte (pure mineral) & & & 62.85 & & & & & & & & & & [82] \\
\hline Ferrihydrite (pure mineral) & & & 66.21 & & & & & & & & & & [82] \\
\hline Wüstite (pure mineral) & 0.14 & & 77.37 & 0.07 & & & & & & & & & [82] \\
\hline Siderite (pure mineral) & & & 42.69 & 0.87 & 0.07 & 0.08 & & 609.86 & 0.88 & & & & [82] \\
\hline
\end{tabular}


Table A1. Cont.

\begin{tabular}{|c|c|c|c|c|c|c|c|c|c|c|c|c|c|}
\hline Location and Type & $\mathrm{SiO}_{2}$ & $\mathrm{P}_{2} \mathrm{O}_{5}$ & $\mathrm{Fe}$ & Mn & $\mathrm{Ca}$ & $\mathrm{Mg}$ & $\mathrm{S}$ & $\mathrm{Fe} / \mathrm{Mn}$ & $\mathrm{Ca} / \mathrm{Mg}$ & $\mathrm{P} / \mathrm{Fe}$ & $\mathrm{Fe} / \mathrm{S}$ & $\begin{array}{c}(\mathrm{CaO}+\mathrm{MgO}) / \\
\mathrm{SiO}_{2}\end{array}$ & $\begin{array}{c}\text { Data Source } \\
\text { (See References) }\end{array}$ \\
\hline & \multicolumn{7}{|c|}{$(\%)$} & - & - & - & - & - & \\
\hline Vivianite (pure mineral) & 0.10 & 27.17 & 34.27 & & & & & & & 0.346 & & & [82] \\
\hline Metavivianite (pure mineral) & & 28.40 & 30.23 & 3.25 & 0.36 & & & 83.97 & & 0.410 & & & [82] \\
\hline Strengite (pure mineral) & & 38.24 & 30.34 & & & & & & & 0.550 & & & [82] \\
\hline Beraunite (pure mineral) & & 30.17 & 39.52 & & & & & & & 0.333 & & & [82] \\
\hline Phosphosiderite (pure mineral) & & 38.85 & 30.97 & & & & & & & 0.547 & & & [82] \\
\hline Tomahawk Lake, USA (Fe-rich nodules) & 8.02 & 3.27 & 54.44 & 1.14 & 0.23 & & & 236.70 & & 0.026 & & 0.040 & [70] \\
\hline Tomahawk Lake, USA (Mn-rich nodules) & 0.27 & 0.20 & 0.50 & 52.88 & 1.09 & & & 0.46 & & 0.174 & & 5.652 & {$[70]$} \\
\hline Hershey Bay, USA (Fe-rich nodules) & 7.40 & 2.88 & 54.86 & 1.14 & 0.65 & & & 84.40 & & 0.023 & & 0.123 & [70] \\
\hline Hershey Bay, USA (Mn-rich nodules) & & 0.24 & 2.05 & 41.19 & 2.62 & & & 0.78 & & 0.051 & & & [70] \\
\hline Tomahawk Lake, USA (mean for nodules) & 4.15 & 1.74 & 27.47 & 27.01 & 0.66 & & & 118.58 & & 0.100 & & 2.846 & {$[70]$} \\
\hline Hershey Bay, USA (mean for nodules) & 3.70 & 1.56 & 28.46 & 21.17 & 1.64 & & & 42.59 & & 0.037 & & 0.061 & {$[70]$} \\
\hline $\begin{array}{l}\text { Green Bay, USA-CAN } \\
\text { (freshwater nodules) }\end{array}$ & & & 27.30 & & & & & & & & & & {$[70]$} \\
\hline $\begin{array}{l}\text { Northern Lake Michigan, USA-CAN } \\
\text { (nodules) }\end{array}$ & & & 12.40 & & & & & & & & & & {$[70]$} \\
\hline Lake Ontario, USA-CAN (nodules) & & & 20.50 & & & & & & & & & & {$[70]$} \\
\hline Lake Oneida, USA (nodules) & & & 23.00 & & & & & & & & & & [70] \\
\hline Baltic Sea nodules, POL (type V) & 35.30 & 1.91 & 12.88 & 13.69 & 1.00 & 1.13 & & 12.88 & 0.88 & 0.065 & & 0.093 & [83] \\
\hline Baltic Sea nodules, POL (type T) & 57.96 & 0.96 & 8.31 & 2.33 & 0.44 & 1.44 & & 18.89 & 0.31 & 0.050 & & 0.052 & {$[83]$} \\
\hline Baltic Sea nodules, POL (type I) & 49.62 & 1.29 & 11.29 & 3.97 & 0.59 & 1.42 & & 19.14 & 0.42 & 0.050 & & 0.064 & [83] \\
\hline Baltic Sea nodules, POL (type D) & 47.62 & 1.32 & 10.86 & 5.22 & 0.73 & 1.30 & & 14.88 & 0.56 & 0.053 & & 0.067 & [83] \\
\hline $\begin{array}{l}\text { Zalew Szczeciński (Szczecin Lagoon), POL } \\
\quad \text { (micronodules in lacustrine bog ore) }\end{array}$ & 37.70 & 3.40 & 16.44 & 0.47 & 4.31 & 0.20 & 0.40 & 3.81 & 21.55 & 0.090 & 41.1 & 0.169 & This study \\
\hline $\begin{array}{l}\text { Dabie Lake, POL (micronodules in } \\
\text { lacustrine bog ore) }\end{array}$ & 7.90 & 2.64 & 48.84 & 3.34 & 4.12 & 3.50 & 1.12 & 11.85 & 1.18 & 0.024 & 43.6 & 1.466 & This study \\
\hline
\end{tabular}




\section{References}

1. Kotliński, R.; Maciag, Ł.; Zawadzki, D. Potential and Recent Problems of the Possible Polymetallic Sources in the Oceanic Deposits. Geol. Miner. Resour. World Ocean 2015, 40, 65-80.

2. Taylor, G.; Eggleton, R.A.; Foster, L.D.; Tilley, D.B.; Le Gleuher, M.; Morgan, C.M. Nature of the Weipa Bauxite deposit, northern Australia. Aust. J. Earth Sci. 2008, 55, 45-70. [CrossRef]

3. Rzepa, G.; Ratajczak, T. Polskie Rudy Darniowe; Wydawnictwa AGH: Kraków, Poland, 2011; pp. 1-369.

4. Bricker, O.P.; Newell, W.L.; Simon, N.S. Bog Iron Formation in the Nassawango Creek Watershed, Maryland, USA. In Geo-Environment: Monitoring and Remediation of the Geological Environment First International Conference on Monitoring, Simulation and Remediation of the Ecological Environment, GEO-ENVIRONMENT 2004; Martin Duque, J.F., Brebbia, C.A., Godfrey, A.E., Diaz de Teran, J.R., Eds.; USGS: Segovia, Spain, 2004; pp. 13-23. [CrossRef]

5. Thorne, R.L.; Anand, R.R.; Suvorova, A. The formation of fluvio-lacustrine ferruginous pisoliths in the extensive palaeochannels of the Yilgarn Craton, Western Australia. Sediment. Geol. 2014, 313, 32-44. [CrossRef]

6. Lascelles, D.F. The origin of terrestrial pisoliths and pisolitic iron ore deposits: Raindrops and sheetwash in a semi-arid environment. Sediment. Geol. 2016, 341, 232-244. [CrossRef]

7. Halbach, P. Mineralogical and geochemical investigations on Finnish lake ores. Bull. Geol. Soc. Finl. 1975, 48, 33-42. [CrossRef]

8. Szamałek, K. Badania izotopowe pizolitowych kaolinów z okolic Assuanu (Egipt). Przegląd Geologiczny 1991, 461, 420-422.

9. Szamałek, K.; Barczuk, A.; El Sayed, A.A.Y. Genesis and mineralogy of lateritic kaolin at Aswan area (SW Egypt). Archiwum Mineralogiczne 1993, 49, 81-97.

10. Singh, B.; Gilkes, R.J. Nature and properties of iron rich glaebules and mottles from some south-west Australian soils. Geoderma 1996, 71, 95-120. [CrossRef]

11. Mukhopadhyay, J.; Gutzmer, J.; Beukes, N.J.; Bhattacharya, H.N. Geology and Genesis of the Major Banded Iron Formation-Hosted High-Grade Iron Ore Deposits of India. Rev. Econ. Geol. 2008, 15, 291-316. [CrossRef]

12. Anand, R.R.; Verrall, M. Biological origin of minerals in pisoliths in the Darling Range of Western Australia. Aust. J. Earth Sci. 2011, 58, 823-833. [CrossRef]

13. Kaczorek, D.; Sommer, M. Micromorphology, chemistry, and mineralogy of bog iron ores from Poland. Catena 2003, 54, 393-402. [CrossRef]

14. Werońska, A. Wpływ warunków środowiska na powstawanie holoceńskich złóż żelaza. Gospodarka Surowcami Mineralnymi 2009, 25, 23-36.

15. Jóźwiak, K. Bogs iron ore in the marshy ground areas-E.g. Kampinoski National Park. Biuletyn Państwowego Instytutu Geologicznego 2011, 445, 237-244.

16. Rzepa, G.; Bajda, T.; Gaweł, A.; Debiec, K.; Drewniak, L. Mineral transformations and textural evolution during roasting of bog iron ores. J. Therm. Anal. Calorim. 2016, 123, 615-630. [CrossRef]

17. Fedoroff, N.; Courty, M.A.; Guo, Z. Palaeosoils and Relict Soils: A Conceptual Approach. In Interpretation of Micromorphological Features of Soils and Regoliths, 2nd ed.; Stoops, G., Marcelino, V., Mees, F., Eds.; Elsevier: Amsterdam, The Netherlands, 2018; pp. 821-862. [CrossRef]

18. Boulangé, B. Les Formations Bauxitiques Latéritiques de Côte d'Ivoire. In Les Facies, Leur Transformation, Leur Distribution et L'évolution du Modelt; Trav. Docum. 175; ORSTOM: Paris, France, 1984; pp. 1-365.

19. Tardy, Y. Petrology of Laterites and Tropical Soils; A.A. Balkema Publishers: Rotterdam, The Netherlands, 1997; pp. 1-419.

20. Łydka, K. Petrologia Skał Osadowych; Wydawnictwa Geologiczne: Warszawa, Poland, 1985; pp. 1-286.

21. Horbe, A.M.; Anand, R.R. Bauxite on igneous rocks from Amazonia and Southwestern of Australia: Implication for weathering process. J. Geochem. Explor. 2011, 111, 1-12. [CrossRef]

22. Nahon, D.B. Introduction to the Petrology of Soils and Chemical Weathering; John Wiley \& Sons Inc.: New York, NY, USA, 1991; pp. 1-313.

23. Anand, R.R.; Paine, M. Regolith geology of the Yilgarn Craton, Western Australia: Implications for exploration. Aust. J. Earth Sci. 2002, 49, 3-162. [CrossRef]

24. Ryka, W.; Maliszewska, A. Stownik Petrograficzny; Wydawnictwa Geologiczne: Warszawa, Poland, 1991; pp. 1-413. 
25. Ljunggren, P. Differential thermal analysis and X-ray examination of Fe and Mn bog ores. Geologiska Foreningens i Stockholm Forhandlingar 1955, 77, 135-147. [CrossRef]

26. De Geyter, G.; Vandenberghe, R.G.; Verdonck, L.; Stoops, G. Mineralogy of Holocene bog iron ore in northern Belgium. Neues Jahrb. Mineral. Abh. 1985, 163, 1-17.

27. Landuydt, C.J. Micromorphology of Iron Minerals from Bog Ores of the Belgian Campine Area. Dev. Soil Sci. 1990, 19, 289-294. [CrossRef]

28. Cornell, R.M.; Schwertmann, U. The Iron Oxides. Structure, Properties, Reactions, Occurrences and Uses; VCH: Weinheim, Germany, 1998; pp. 1-664. [CrossRef]

29. Stoops, G. SEM and Light Microscopic Observations of Minerals in Bog-Ores of the Belgian Campine. Dev. Soil Sci. 1983, 12, 179-186. [CrossRef]

30. Mermut, A.R.; Dasog, G.S. Nature and Micromorphology of Carbonate Glaebules in Some Vertisols of India. Soil Sci. Soc. Am. J. 1986, 50, 382-391. [CrossRef]

31. Gallaher, R.N.; Perkins, H.F.; Tan, K.H. Chemical and mineralogical changes in glaebules and enclosing soil with depth in a plinthic soil. Soil Sci. 1974, 117, 336-342. [CrossRef]

32. Piotrowski, S. Geochemical characteristics of bottom sediments in the Odra River estuary-Roztoka Odrzańska (north-west Poland). Geol. Q. 2004, 48, 61-76.

33. Copernicus Sentinel Data 2016 \& 2017. EOX IT Services GmBH. Available online: https://sentinel.esa.int (accessed on 1 May 2019).

34. Buchholz, W.; Kreft, A.; Parzonka, W.; Coufal, R.; Meyer, Z. Warunki hydrologiczne estuarium Odry. In Regionalne Problemy Gospodarki Wodnej i Hydrotechniki; Wydawnictwo Uczelniane PS: Szczecin, Poland, 2004; pp. 11-20.

35. Piotrowski, A. Objaśnienia do Szczegółowej Mapy Geologicznej Polski 1:50,000, Arkusz Police (190); Wyd. Państwowego Instytutu Geologicznego: Warszawa, Poland, 1982; pp. 1-82.

36. Malinowski, R.; Niedźwiecki, E.; Kowalski, W.A.; Protasowicki, M. Charakterystyka wybranych elementów środowiska przyrodniczego Wyspy Chełminek. Cz. I. Różnicowanie się cech morfologicznych i właściwości gleb powstających z piaszczystych osadów dennych w wyniku ich zalesienia na wyspie Chełminek. Folia Pomer. Univ. Technol. Stetin. Ser. Agric. Aliment. Pisc. Zootech 2012, 300, 73-82.

37. Kowalewska-Kalkowska, H. Rola Wezbrań Sztormowych w Kształtowaniu Ustroju Wodnego Układu Dolnej Odry $i$ Zalewu Szczecińskiego; Wydawnictwo Naukowe US: Szczecin, Poland, 2012; pp. 1-258.

38. Borówka, R. Krajobrazy Zalewu Szczecińskiego i jego otoczenia. Prace Komisji Paleogeografii Czwartorzędu Polskiej Akademii Umiejętności 2003, 1, 89-91.

39. Duda, T. Sedymentacja osadów fluwialnych w Dolinie Dolnej Odry rozwijającej się pod wpływem długotrwałego wzrostu poziomu morza. In Rozprawy i Studia (945)871; Wydawnictwo Naukowe US: Szczecin, Poland, 2013; pp. 1-156.

40. Poleszczuk, G.; Piesik, Z. On differences in chemical composition occurring between surface and near bottom water in the Szczecin Lagoon. Balt. Coast. Zone 2000, 4, 27-43.

41. Landsberg-Uczciwek, M.; Złoczorska, I.; Kordas, A.; Wierzchowska, E.; Mazur-Chrzanowska, B.; Sroka, E.; Konon-Szatkowska, H.; Gajdecki, A. Ocena Jakości wód Powierzchniowych w Województwie Zachodniopomorskim za 2015 Rok; Archiwum WIOŚ w Szczecinie: Szczecin, Poland, 2016.

42. Nałęcz, T. Geochemical Atlas of Szczecin Agglomeration, Part II; Ekologicznej, S.A., Ed.; Wydawnictwo Kartograficzne Polskiej Agencji: Warszawa, Poland, 1998; pp. 1-16.

43. Romanowska-Duda, Z. Metale ciężkie jako specyficzne zanieczyszczenia środowiska wodnego. Acta Innov. 2015, 15, 1-18.

44. Lis, J.; Pasieczna, A. Geochemical Atlas of Szczecin Agglomeration, Part I; Ekologicznej, S.A., Ed.; Wydawnictwo Kartograficzne Polskiej Agencji: Warszawa, Poland, 1998; pp. 1-18.

45. Borówka, R.; Skowronek, A.; Osadczuk, A.; Witkowski, A.; Maciag, Ł.; Tomkowiak, J.; Bieniek, B.; Kosińska, B. Litologia i geochemia osadów wschodniej części Zalewu Szczecińskiego (Zalew Wielki). In Budowa Geologiczna Potudniowego Battyku i Pomorza Środkowego Oraz Aktualne Problemy Geologii Morza w Perspektywie Polskich Badań Oceanicznych, Proceedings of the 85 Zjazd Naukowy Polskiego Towarzystwa Geologicznego, Koszalin, Poland, 18-21 September 2017; Państwowy Instytut Geologiczny-Państwowy Instytut Badawczy PGI-PIB: Warszawa, Poland, 2017; pp. 43-50.

46. Piotrowski, S. Zawartość metali ciężkich (Cu, Zn, Pb, Co, Cd, Hg) w wybranych elementach ekosystemu estuarium Odry. Przegląd Geologiczny 2007, 55, 193-197. 
47. Lithogenetic Map of Poland. Available online: www.geolog.gov.pgi.pl (accessed on 1 June 2019).

48. Grazulis, S.; Chateigner, D.; Downs, R.T.; Yokochi, A.T.; Quiros, M.; Lutterotti, L.; Manakova, E.; Butkus, J.; Moeck, P.; Le Bail, A. Crystallography Open Database-An open-access collection of crystal structures. J. Appl. Cryst. 2009, 42, 726-729. [CrossRef]

49. Alvarez, M.; Sileo, E.E.; Rueda, E.H. Structure and reactivity of synthetic Co-substituted goethites. Am. Mineral. 2008, 93, 584-590. [CrossRef]

50. Gualtieri, A.; Venturelli, P. In situ study of the goethite-hematite phase transformation by real time synchrotron powder diffraction. Am. Mineral. 1999, 84, 895-904. [CrossRef]

51. Patrat, G.; de Bergevin, F.; Pernet, M.; Joubert, J.C. Structure locale de $\delta$-FeOOH. Acta Crystallogr. Sect. B Struct. Sci. 1983, 39, 165-170. [CrossRef]

52. Goldsztaub, M. Etude de quelques derives de l'oxyde ferrique $\left(\mathrm{FeOOH}, \mathrm{FeO}_{2} \mathrm{Na}, \mathrm{FeOCl}\right)$ determination de leurs structures. Bulletin de la Societe Francaise de Mineralogie 1935, 58, 6.

53. Jansen, E.; Kyek, A.; Schafer, W.; Schwertmann, U. The structure of six-line ferrihydrite. Appl. Phys. A 2002, 74, 1004-1006. [CrossRef]

54. Zhang, J.; Guyot, F. Thermal equation of iron and $\mathrm{Fe}_{0.91} \mathrm{Si}_{0.09}$. Phys. Chem. Mineral. 1999, 26, $206-211$. [CrossRef]

55. Mori, H.; Ito, T. The structure of vivianite and symplesite. Acta Crystallogr. 1950, 3, 1-6. [CrossRef]

56. Chukanov, N.V.; Scholz, R.; Aksenov, S.M.; Rastsvetaeva, R.K.; Pekov, I.V.; Belakovskiy, D.I.; Krambrock, K.; Paniago, R.M.; Righi, A.; Martins, R.F.; et al. Metavivianite, $\mathrm{Fe}^{2+} \mathrm{Fe}^{3+}{ }_{2}\left(\mathrm{PO}_{4}\right)_{2}(\mathrm{OH})_{2} \cdot 6 \mathrm{H}_{2} \mathrm{O}$ : New data and formula revision. Mineral. Mag. 2012, 76, 725-741. [CrossRef]

57. Lavina, B.; Dera, P.; Downs, R.T.; Yang, W.; Sinogeikin, S.; Meng, Y.; Shen, G.; Schiferl, D. Structure of siderite $\mathrm{FeCO}_{3}$ to $56 \mathrm{GPa}$ and hysteresis of its spin-pairing transition. Phys. Rev. B 2010, 82, 110-118. [CrossRef]

58. Gualtieri, A.F. Accuracy of XRPD QPA using the combined Rietveld-RIR method. J. Appl. Crystallogr. 2000, 33, 267-278. [CrossRef]

59. Gournis, D.; Lappas, A.; Karakassides, M.A.; Tobbens, D.; Moukarika, A. A neutron diffraction study of alkali cation migration in montmorillonites. Phys. Chem. Mineral. 2008, 35, 49-58. [CrossRef]

60. Nickel, E.H. New data on woodwardite. Mineral. Mag. 1976, 43, 644-647. [CrossRef]

61. Witzke, T.; Raade, G. Zincowoodwardite, $\left[\mathrm{Zn}_{1-\mathrm{x}} \mathrm{Al}_{\mathrm{x}}(\mathrm{OH})_{2}\right]\left[\left(\mathrm{SO}_{4}\right)_{\mathrm{x} / 2}\left(\mathrm{H}_{2} \mathrm{O}\right)_{\mathrm{n}}\right]$, a new mineral of the hydrotalcite group. Neues Jahrbuch für Mineralogie Monatshefte 2000, 10, 455-465.

62. Effenberger, H.; Mereiter, K.; Zemann, J. Crystal structure refinements of magnesite, calcite, rhodochrosite, siderite, smithonite, and dolomite, with discussion of some aspects of the stereochemistry of calcite type carbonates. Zeitschrift für Kristallographie, Kristallgeometrie, Kristallphysik, Kristallchemie 1981, 156, $233-243$.

63. Fjellvag, H.; Hauback, B.C.; Vogt, T.; Stolen, S. Monoclinic nearly stoichiometric wüstite at low temperatures. Am. Mineral. 2002, 87, 347-349. [CrossRef]

64. Virtanen, K. Geological control of iron and phosphorous precipitates in mires of the Ruukki-Vihanti area, Central Finland. Bull. Geol. Surv. Finl. 1994, 375, 1-69.

65. Postma, D. Formation of siderite and vivianite and the porewater composition of a recent bog sediment in Denmark. Chem. Geol. 1981, 31, 225-244. [CrossRef]

66. Postma, D. Pyrite and siderite formation in brackish and freshwater swamp sediments. Am. J. Sci. 1982, 282, 1151-1183. [CrossRef]

67. Wang, J.; Chen, J.; Guo, J.; Sun, Q.; Yang, H. Combined Fe/P and Fe/S ratios as a practicable index for estimating the release potential of internal-P in freshwater sediment. Environ. Sci. Pollut. Res. 2018, 25, 10740-10751. [CrossRef]

68. Jensen, H.S.; Kristensen, P.; Jeppesen, E.; Skytthe, A. Iron:phosphorus ratio in surface sediment as an indicator of phosphate release from aerobic sediments in shallow lakes. Hydrobiologia 1992, 235, 731-743. [CrossRef]

69. Migaszewski, Z.M.; Gałuszka, A. Geochemia Środowiska; Wydawnictwa Naukowe PWN: Warszawa, Poland, 2007; pp. 1-574.

70. Jones, B.F.; Bowser, C.J. The mineralogy and related chemistry of lake sediments. In Lakes, Chemistry, Geology, Physics; Lerman, A., Ed.; Springer: New York, NY, USA, 1978; pp. 179-236.

71. Mozley, P.S. The internal structure of carbonate concretions in mudrocks: A critical evaluation of the conventional concentric model of concretion growth. Sedim. Geol. 1996, 103, 85-91. [CrossRef]

72. Clarke, J.D.A.; Chenoweth, L. Classification, genesis and evolution of ferruginous surface grains. AGSO J. Aust. Geol. Geophys. 1996, 16, 213-221. 
73. Depowski, S.; Kotliński, R.; Rühle, E.; Szamałek, K. Surowce Mineralne Mórz i Oceanów; Wydawnictwo Naukowe SCHOLAR: Warszawa, Poland, 1998; pp. 1-384.

74. Szamałek, K.; Uścinowicz, S.; Zglinicki, K. Rare earth elements in Fe-Mn nodules from southern Baltic Sea-A preliminary study. Biuletyn Państwowego Instytutu Geologicznego 2018, 472, 199-212. [CrossRef]

75. Kraczkowska, I.; Ratajczak, T.; Rzepa, G. Skład mineralny oraz właściwości fizykomechaniczne kawałkowych odmian rud darniowych stosowanych w historycznym budownictwie na ziemiach polskich. Przegląd Geologiczny 2001, 49, 1147-1156.

76. Scott, P.W.; Ealey, P.J.; Rollinson, G.K. Bog iron ore from Lowland Point, St Keverne, Lizard, Cornwall. Geosci. South-West Engl. 2011, 12, 260-268.

77. Kociszewska-Musiał, G. Surowce Mineralne Czwartorzędu; Wydawnictwa Geologiczne: Warszawa, Poland, 1988; pp. 1-280.

78. Warencow, I.; Błaszczyszyn, A. Konkrecje manganowe w dnie Morza Bałtyckiego. In Geologia Morza Bałtyckiego; Gudelis, W.K., Jemielianow, J.M., Eds.; Wydawnictwa Geologiczne: Warszawa, Poland, 1982; pp. 307-345.

79. Białaczewski, A. Rudy darniowe. In Budowa Geologiczna Polski, Złoża Surowców Mineralnych; Osika, R., Ed.; Wydawnictwa Geologiczne: Warszawa, Poland, 2007; Volume 6, pp. 278-282.

80. Kotlarczyk, J.; Ratajczak, T. Ochra Karpacka z Czerwonek Hermanowskich koło Tyczyna; Wydawnictwo IGSMiE PAN: Kraków, Poland, 2002; pp. 1-120.

81. Wyderko-Delekta, M.; Bolewski, A. Mineralogia Spieków i Grudek Rudnych; Wydawnictwa AGH: Kraków, Poland, 1995; pp. 1-280.

82. Mineral Data Publishing, Version I. Available online: www.webmineral.com (accessed on 1 June 2019).

83. Zglinicki, K.; Szamałek, K.; Uścinowicz, S.; Damrat, M.; Szefler, K.; Nowak, J.; Zhamoida, V.; Krek, A.; Bubnova, E. Metale w konkrecjach Fe-Mn z polskiego sektora Morza Bałtyckiego. In Proceedings of the II Konferencja Naukowa Polskich Badaczy Morza, Gdynia, Poland, 24-25 September 2019. [CrossRef]

(C) 2019 by the authors. Licensee MDPI, Basel, Switzerland. This article is an open access article distributed under the terms and conditions of the Creative Commons Attribution (CC BY) license (http://creativecommons.org/licenses/by/4.0/). 